THE NORTH CAROLINA FIELD TEST: EXPERIMENTAL PLAN

T. R. Sharp

M. P. Ternes

Weatherization Assistance Program

August 1990

\author{
Prepared for the \\ Office of State and Local Assistance Programs \\ U.S. Department of Energy
}

\author{
Prepared by the \\ OAK RIDGE NATIONAL LABORATORY \\ Oak Ridge, Tennessee 37831 \\ Operated by \\ MARTIN MARIETTA ENERGY SYSTEMS, INC. \\ for the \\ U.S. DEPARTMENT OF ENERGY \\ under Contract No. DE-ACO5-840R21400
}
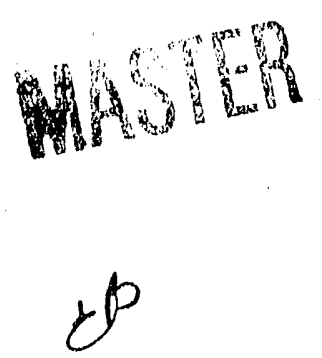


\section{CONTENTS}

LIST OF FIGURES. . . . . . . . . . . . . . . . . . . . . . . . . v

LIS'T OF TABLES ............................ . . . . . . . . . . . .

ACKNOWLEDGMENTS . . . . . . . . . . . . . . . ix

ABSTRACT . . . . . . . . . . . . . . . . . . . . $x i$

EXECUTIVE SUMMARY."..................... xiii

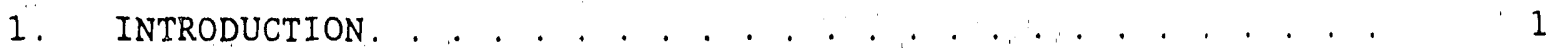

1.1 BACKGROUND , . . . . . . . . . . . . . . . : . . . . . . 1

1.2 FIELD TEST AND REPORT OBJECTIVES . . . . . . . . . . . .

1.3 REPORT ORGANIZATION..................... . . . 2

2. PROJECT OVERVIEW. . . . . . . . . . . . . . . . . . . . . . . 3

2.1 GENERAL APPROACH . . . . . . . . . . . . . . . . . . . . . 3

2.2 RESEARCH GOALS AND QUESTIONS . . . . . . . . . . . . . . 5

2.3 PROJECT PARTICIPANTS AND CONTRIBUTIONS . . . . . . . . . . . 7

2.4 PROJECT TASKS AND SCHEDULE . . . . . . . . . . . . . . . . 8

3. CONSERVATION APPROACHES . . . . . . . . . . . . . . . . . . 15

3.1 NORTH CAROLINA'S CURRENT LOW-INCOME WAP. . . . . . . . . 15

3.2 THE FIELD TEST AUDIT . . . . . . . . . . . . . . . 16

4. FIELD TEST DESIGN AND IMPLEMENTATION. . . . . . . . . . . . . . 17

4.1 EXPERIMENTAL DESIGN . . . . . . . . . . . . . . 17

4.2 HOME ELIGIBILITY . . . . . . . . . . . . . . . . . . . . 17

4.3 SELECTION PROCEDURE. . . . . . . . . . . . . . . . . . 20

4.4 ASSIGNMENT PROCEDURE . . . . . . . . . . . . . . . . . . 21

5. DATA PARAMETERS AND MONITORING INSTRUMENTATION. . . . . . . . 27

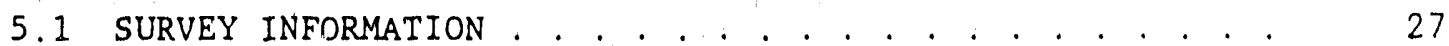

5.2 TIME-SEQUENTIAL MEASUREMENTS . . . . . . . . . . . . . . 32

5.2.1 House Electricity Use . . . . . . . . . . . . . . 34

5.2.2 Space Heating Fuel Use. . . . . . . . . . . . . . 34

5.2.3 Air Conditioner Electricity Use . . . . . . . . . 35

5.2.4 Water Heating Electricity Use. . . . . . . . . . 35

5.2.5 Indoor Temperature. . . . . . . . . . . . . . . . 36

5.2.6 Ambient Weather Parameters. . . . . . . . . . 36 
6. Data Management . . . . . . . . . . . . . . . . . 39

6.1 SURVEY INFORMATION . . . . . . . . . . . . . . . . . . . . 39

6.2 TIME-SEQUENTIAL MEASUREMENTS . . . . . . . . . . . . . . 40

7. DATA ANALYSIS . . . . . . . . . . . . . . . . . . . 45

7.1 HOUSE AND OCCUPANT CHARACTERISTICS ... . . . . . . . . 45

7.2 WEATHERIZATION MEASURES. . . . . . . . . . . . . . . . . 45

7.3 ENERGY SAVINGS AND PERFORMANCE . . . . . . . . . . . 45

7.3.1 Individual House Savings. . . . . . . . . . . . . 46

7.3.2 Group Savings . . . . . . . . . . . . . . . . . . 47

7.3.3 Cost Effectiveness of Weatherization. ... . . . . 47

7.3.4 Implementation of the Audit Procedures . . . . . 47

8. REFERENCES. . . . . . . . . . . . . . . . . . 49

Appendix A. SURVEY INTERVIEW FORM . . ... . . . . . . . . . . . . 51

Appendix B. DATA LOGGER SPECIFICATIONS. . . . . . . . . . . . . 63 


\section{LIST OF FIGURES}

2.1 Task scheduling for the three project areas of the North Carolina Field Test . . . . . . . . . . . . . . . . . . 9

4.1 North Carolina house screening checklist. . . . . . . . . . . 22

4.2 Summary of the North Carolina Field Test for participating households. . . . . . . . . . . . . . . 23

4.3 Household agreement form. . . . . . . . . . . . . . . 25

5.1 Data requirements and corresponding collection schedule. . . 28

6.1 Data management procedure for the survey information. . . . . 41

6.2 Weekly field data collection form . . . . . . . . . . . . . . 42

6.3 Data management procedure for the time-sequential
measurements. . . . 44 


\section{LIST OF TABLES}

5.1 House descriptive information. . . . . . . . . . . . . 30

5.2 Space conditioning systems descriptive information. . . . . . 31

5.3 Entrance interview information. . . . . . . . . . . . . 31

5.4 Follow-up and exit interviow information . . . . . . . . . . 31

5.5 Time-sequential data parameter requirements and information. . 33 
The authors would like to express their appreciation to Ms. Mary Fowler, Director, and Ms. Veronica Johnson of the DOE Weatherization Assistance Program, Mr. Fred Singleton of the DOE Atlanta Support Office, Mr. Earnie Freeman of the DOE Office of Buildings, and Community systems, Messrs. Jeff Brown and Mr. Percy Carter of the State of North Carolina, and the North Carolina Alternative Energy Corporation for their support of the North Carolina Field Test. A special note of thanks to Mr. Mark Hopkins of the Alliance to Save Energy for his work in preparation of the concepi paper from which the field test originated. Our appreciation is also extended to Mr. Francis Conlin of the North Carolina Alternative Energy Corporation and to Messrs. Mike MacDonald and Mike Gettings of the Oak Ridge National Laboratory for valuable commentary on the experimental plan. 


\begin{abstract}
The North Carolina Field Test will test the effectiveness of two weatherization approaches: the current North Carolina Low-Income Weatherization Assistance Program and the North Carolina Field Test Audit. The Field Test Audit will differ from North Carolina's current weatherization program in that it will incorporate new weatherization measures and techniques, a procedure for basing measure selection on the characteristics of the individual house and the cost-effectiveness of the measure, and also emphasize cooling energy savings. The fleld test will. determine the differences of the two weatherization approaches froin the viewpoints of energy savings, cost effectiveness, and implementation ease. This Fxperimental Plan details the steps in performing the field test. The flelu test will be a group effort by several participating organizations.

Pre- and post-weatherization data will be collected over a two-year period (November 1989. through August 1991). The 120 houses included in the test will be divided into a control group and two treatment groups (one for each weatherization procedure; of 40 houses each. Weekly energy use data will be collectel for each house representing whole-house electric, space heating and cooling, and water heating energy uses. Corresponding outdoor weather and house indoor temperature data will also be collected.

The energy savings of each house will be determined using linearregression based models. To account for variations between the pre- and postweatherization periods, house energy savings will be normalized for differences in outdoor weather conditions and indoor temperatures. Differences between the average energy savings of treatment groups will be identified using an analysis of variance approach. Differences between energy savings will be quantifled using multiple comparison techniques. The control group will be used to normalize for occupancy variations between the pre-and post-weatherization periods.
\end{abstract}




\section{EXECUTIVE SUMMARY}

This report documents the experimental plan for the North Carolina Field Test. The Field Test will test the effectiveness of two weatherization approaches: the current North Carolina Low-Income Weatherization Assistance Program and the North Carolina Field Tes: Audit. The field test is being conducted as part of Phase 1 of a projeot to revise the current measure selection process used in DOE's Low Income Weatherization Assistance Program (Project Retrotech). The Field Test Audit will differ from North Carolina's current weatherization program in that it will:

1. incorporate new weatherization measures and techniques,

2. incorporate a procedure for basing measure selection on the characteristics of an individual house and the cost. effectiveness of the measure, and

3. etuphasize cooling energy savings.

The field test will determine the differences of the two weatherization approaches from the viewpoints of energy savings, costs effectiveness, and implementation ease. It will also determine if the additional requirements of the new audit are cost justified. Testing of the new audit approach will allow the feasibility and cost effectiveness of the latest weatherization techniques and methods to be determined.

The field test is being supported by the U.S. Department of Energy's (DOE) Office of State and Local Assistance Programs; the DOE Office of Buildings and Community Systems; and the DOE Atlanta support office. Organizations involved in the day-to-day activities of the field test include the North Carolina Department of Economic and Community Development (NC-DECD) - Energy Division, the North Carolina Alternative Energy Corporation (NCAEC), the Oak Ridge National Laboratory (ORNL), the Alliance to Save Energy, and thixee local Weatherization Assistance Program (WAP) providers (Franklin/Vance/Warren Opportunity, Johnston-Lee Community Action, and FourCounty Community Services). 
The North Carolina Field Test will be performed using 120 houses in eastern North Carolina. Conservation measures selected by the Field Test Audit will be installed in one-third of the houses (audit houses), measures selected following North Carolina's current WAP procedure will be installed in another third of the houses (current practice houses); and the remaining houses will serve as a control group (control houses). Testing will be conducted over a two-year period (November 1989 to August 1991). Weatherizations will be performed in the middle of the test period to allow approximately one year each for pre- and post-weatherization testing. Tests will be performed to determine the energy savings of individual houses and groups of houses (treatment groups). Pre- and post-weatherization testing will allow houses to serve as their own reference and thus, allow individual house savings to be determined.

Data will be collected through surveys and continuous monitoring. Typical survey data will consist of descriptive details of the house construction and its mechanical system(s), short-term performance evaluations of the bullding shell and/or mechanical system(s), and detafls of occupancy levels and patterns. Survey data will be used to document house characteristics and their impacts on energy use. Monitored data will include weekly measurements of the following energy uses: whole-house electriclty, space heating, air conditioning, and water heating. In addition, outdoor weather data and house indoor temperature data will be recorded on an hourly basis.

Ultimately, all field data will be computerized and meshed to form the final data sets from which analyses will be done. The NC-DECD and the NCAEC will direct data collection and provjde data to the ORNI for processing (error identification, correction, and meshing into final data sets).

Both survey information and performance data will be analyzed. Analyses will answer questions about house and occupant characteristics, weatherization measures, weatherization energy savings, and the performance of the two weatherization approaches. Survey information will be used to 
characterize house' types, floor areas, wall, floor, and celling/attic constructions, space heating and cooling systems, occupancy levels, occupled periods, and other characteristics.

Linear regression techniques will be used, to model the relations between energy use and indoor and outdoor conditions for the pre - and post. weatherization periods for each house. Individual house savings will be adjusted (normalized) for temperature variations (both indoox and outdoor) between the pre- and post-weatherization periods using the models, average outdoor temperature data based on historical records, and values for the indoor temperature. Normalization is done to keep influencing factors from masking or altering the resulting energy savings. Occupant related changes will be accounted for by measuring the before and after energy performance of the control houses. Groups of similar houses (houses with similar characteristics as identified by the characteristics data) will be pooled and analyzed to calculate group savings, compare the savings of the audit houses to the current practice houses, and identify the effect of selected variables on the savings. The ease of implementation of the two weatherization procedures will be compared based on the experience of the auditors and weatherization installers. 


\section{INTRODUCTION}

\subsection{BACKGROUND}

In 1978, "Project Retrotech"1 was published to provide local weatherization agencies a manual means of ldentifying what energy conservation (weatherization) measures could be installed in low-income homes to maximize the energy savings per dollar spent for weatherization. During the eleven years since its publication, weatherization technologtes and program changes evolved such that revision or replacement of this audit was needed. 2 In 1988 , the Department of Energy's (DOE) Weatherization Assistance Program (WAP) initiated a profect with the Oak Ridge National Laboratory (ORNL) to improve the effectiveness of Profect Retrotech. Based on assessment of the current measure selection techniques and the needs of local weatherization agencies, it was recommended that the Weatherization Assistance Program support the development of an upgraded technique. ${ }^{2}$

Following this recommendation, in 1989 the Weatherization Assistance Program approved a project to support development of a new technique for measures selection. The project would be done in two phases: (1) develop an upgraded WAP audit procedure and fleld test 1t against the current North Carolina weatherization procedure, and (2) expand the upgraded WAP audit procedure for use by all WAP agencies.

The ORNL is currently developing the new WAP audit procedure (the field Test Audit) for Phase 1 of the project. This Experimental Plan documents the detalls of the field testing portion of Phase 1 (the North Carolina Fleld Test) which will test side"by"side the current North Carolina weatherization procedure and the new Field Test Audit.

\subsection{FIELD TEST AND REPORT OBJECTIVES}

The primary purpose of the North Carolina Field Test is to:

Determine the energy savings from the current North Carolina Low-Income Weatherization Assistance Program procedure ${ }^{3}$ as compared to a new weatherization approach (the Field Test Audit) which incorporates new 
weatherization techriques and methods and is specifically designed to include cooling and domestic hot water energy saving measures as well as measures for heating energy savings.

The fleld test will determine the differences of the two weatherization approaches from the viewpoints of energy savings, cost effectiveness, and implementation ease. Testing of the new audit approach will allow the feasibility and cost effectiveness of the latest weatherization techniques and methods to be determined.

\subsection{REPORT ORGANIZATION}

Section 2 of this report provides general project details, including how the project will be done, the goals of the project, and the research questions that can be addressed using the project's results. Individual tasks and the responsible participants axe. listed in section 2 along with a project schedule. Section 3 summarizes the two weatherization approaches that will be tested. Section 4 provides detalls of the test design including the size and the proportioning of the sample, the house and occupant characteristics required for inclusion, and how the sample will be obtained and assigned. Sections 5 and 6 summarize data collection detalls. Section 5 outlines the data required for the field test, the types of instrumentation required, and the general details of instrument installation. Section 6 discusses how the data will be collected, assembled, and verified. Section 7 details the analyses that will be performed on the collected data to characterize the test homes, occupants, and the energy savings on an individual house and group basis. Analyses to determine the cost effectiveness of the two weatherization schemes and the ease of implementation of new weatherization options and procedures are also discussed in Section 7. 


\section{PROSECT OVERVIEW}

\subsection{GENERAL APPROACH}

The field test will be performed by the North Carolina Department of Economic and Community Deveiopment (NC-DECD) - Energy Division; the North Carolina Alternative Energy Corporation (NCAEC); the Oak Ridge National Laboratory (ORNL); the Alliance to Save Energy (ASE); and three local weatherization providers (Franklin/Vance/Warren Opportunity, Johnston-Lee Community Action, and Four-County Community Services). Financial support for the project will be provided by the DOE Office of State and Local Assistance Programs which administers the WAP; the DOE Office of Buildings and Community Systems; the DOE Atlanta Support Office; the NCAEC; and the NC-DEZD.

The field test will be performed in counties in eastern North Carolina near Raleigh. One-hundred twenty houses meeting selected criteria will be monitored. Conservation measures selected by the North Carolina Field Test Aulit will be installed in one-third of the houses (audit houses), measures selected following North Carolina's current WAP procedure will be installed in another third of the houses (current practice houses), and the remaining houses will serve as a control group (control houses). The inclusion of a control group allows many factors that may affect the validicy of the experiment to be taken into account. Energy consumption changes in the weatherized houses may be due entirely. to the conservation measures installed. On the other hand, other factors occurring during the test program may contribute to the change. A group of houses identical to the weatherized houses except that measures are not installed (a control group) will be used to account for these other factors by determining their change in energy use over the same time period. The changes in the control group can then be compared to the changes measured in the audit and current practice groups to determine the actual savings induced by the conservation measures. A stratified random assignment procedure will be used to help achieve preweatherization equality between the three groups of houses.

The field test will be conducted over a two-year period. Pre- and postweatherization testing will be performed to determine the change in energy use 
of Individual houses. Pre-weatherization data will be collected on all houses during one winter and summer season (November 1989 to August 1990). Measures will be installed in the treatment houses in September and October 1990. Post-weatherization data will be collected on all houses duxing the following winter and sunmer seasons (November 1990 to August 1991).

Data collection will be based on the recommendations of the DOE's SingleFamily Monitoring Protocol. ${ }^{4}$ The following time-dependent data will be collected weekly in all the houses: house electricity use, space heating energy use, water heating electricity use, and air conditioring electricity use. Hourly indoor temperature data will be monitored in each house and hourly outdoor weather data will be collected at three sites near the houses. The following time-independent information will also be collected or measured during the field test: house and occupant descriptive information, changes that occurred in the descriptive information during the test, house infiltration rates, heating system performance, and descriptions and quality verifications of the conservation measures installed.

Linear regression techniques will be used to mati? the relation between space conditioning energy use and indoor and outdoor conditions for the preand post-weatherization periods for each house. For the winter seasons, the relationship between the space heating energy use and the indoor-outdoor temperature difference will be determined. For the summer seasons, the relations between air conditioning energy use and indoor-outdoor temperature difference and other weather variables will be determined. A house model is needed because ( 1 ) the time periods over which the data will be collected may not be equal or cover the entire rinter and sumer periods, (2) the weather conditions for the pre- and post-periods will likely be different, and

(3) indoor temparatures maintained in each house over the two winter and summer periods will likely not be the same. Normalized annual energy consumptions for the pre- and post-periods will be estimated for each house using the models, average outdoor temperature data based on historical records, and values for the indoor temperature. For each house, the difference between these normalized energy consumptions will be the normalized annual change in energy use. 
The performance of the Field Test Audit and current practice will be evaluated on an individual house and group basis. The change in energy use of each weatherized house will be adjusted by the change that occurred, on average, in the control houses. This adjustment accounts for changes in energy use due to changes in occupant behavior (an influencing factor other than the conservation measures). Individual house savings will be grouped and analyzed to determine group savings, to compare the savings of the audit houses to the current practice houses, and to identify the effect of selected variables on the savings.

Two technical reports outlining the results of the project will be published. The first report (an interim report) will present the preweatherization energy consumptions of the houses. Following the post. weatherization summer season, a second report will present results on the actual energy savings achieved by the conservation measures selected by the audit and current pracrice. Technical papers on the results will be presented at appropriate conferences. A separate memorandum will be prepared summarizing the results and presenting policy and program recommendations. A technical report discussing economic analysis techniques and recommended practices for use in weatherization audits will also be prepared. Finally, a training curriculum for the audit will be developed.

\subsection{RESEARCH GOALS AND QUESTIONS}

The goals of this field test were developed to meet some of the research needs of the Department of Energy's Weatherization Assistance Program. Research results should characterize the importance of cooling energy savings to local weatherization assistance programs. In addition, the results should identify more cost-effective weatherization measures and techniques that can be used to improve the value of services currently provided to low-income families. 
The project has two primary goals:

(1) to determine any improved cost effectiveness resulting from a new audit which includes the latest in now weatherization measures and techniques and is directed toward cooling and water heiting energy savings as well as space heating energy savings, and

(2) to determine the size of potential cooling energy savings as compared to potential heating energy savings from low-income weatherization in a hot and humid climate.

Results of this experiment should help to resolve the following issues in the three categories:

\section{Energy Savings and Performance}

1. What are the typical energy savings achieved from the current North Carolina WAP?

2. What are the typicai energy savings achieved from the new Field Test Audit?

3. How does the cost-effectiveness of the two approaches compare for North Carolina conditions?

4. What are the advantages and disadvantages of using the new audit and its procedures?

5. How do the cooling enexgy savings from low-income weatherization compare to the heating energy savings?

\section{Weatherization Measures}

1. What are the most common energy saving measures installed in low-income houses in North Carolina under the existing WAP? 
2. What are the most common energy saving measures recommended by the field Test Audit? How do they differ from those installed under the existing North Carolina WAP?

\section{House and Occupant Characteristics}

1. What are the characteristics of the typical house and occupant(s) in the field test?

2. Were the two treatment groups and the control group equivalent relative to these house and occupant characteristics?

\subsection{PROSECT PARTICIPANTS AND CONTRIBUTIONS}

Project participants and their contributions (participants are listed in Section 2.1) are as follows:

1. The DOE Weatherization Assistance Program provides support to lowincome weatherization assistance programs across the nation through regional offices such as the DOE Atlanta Support Office. This program is providing funding to support ASE and ORNL tasks.

2. A second DOE program, the Existing Bulldings Efficiency Research (EBER) program of the Office of Building and Community systems, actively promotes energy efficiency research for the nation's existing residential and commercial bulldings. EBER is also providing funding to support ASE tasks and supporting ORNL tasks by contributing necessary monitoring equipment.

3. The DOE Atlanta Support Office is providing funds to support NC-DECD tasks.

4. The NCAEC is a state non-profit research organization working with electric utilities in North Carolina to improve energy efficiency. NCAEC will provide funds and manpower to acquire, install, maintain, and remove metering equipment, and assist in data collection. 
5. The NC-DECD will manege the fleld test by conducting or coordinating all fleld test activities. In addition, they will provide funds to the participating WAP providers, 1.e., the Community Action Programs who will perform the actual weatherizations.

6. The ASE is a national non-profit coalition of business, government, and public leaders dedicated to promoting energy use efficiency. The ASE provided the initial organizing of the project, will support the audit development through economic analysis work, will continue to provide management support to the project, and will prepare some of the profect's publications.

7. The ORNL is a research laboratory whose primary role is to support governmental research programs. ORNL tasks will be to develop the Experimental Plan, the Field Test Audit, provide instrumentation and installation detalls, perform data analyses, and prepare reports documenting the project and its results.

8. The WAP providers will assist in house selection, data collection, audit the participating houses, and perform the weatherizations.

\subsection{PROJECT TASKS AND SCHEDUUE}

The project has been organized into the three areas of Planning and Development, Field T'esting, and Data Analysis and Results Dissemination. Twenty subtasks were identified in the three project areas. These are shown along with their scheduling in Fig. 2.1 and are described as follows:

\subsection{Planning and Development}

1.1 Organize Project. The primary function of this task is to develop a project concept paper which describes the project, its purpose and approach, its tasks, and the participants and their roles. The ASE, with input from profect participants, completed their part of this task in March 1989. ORNL completed their project organization efforts in April 1989. 


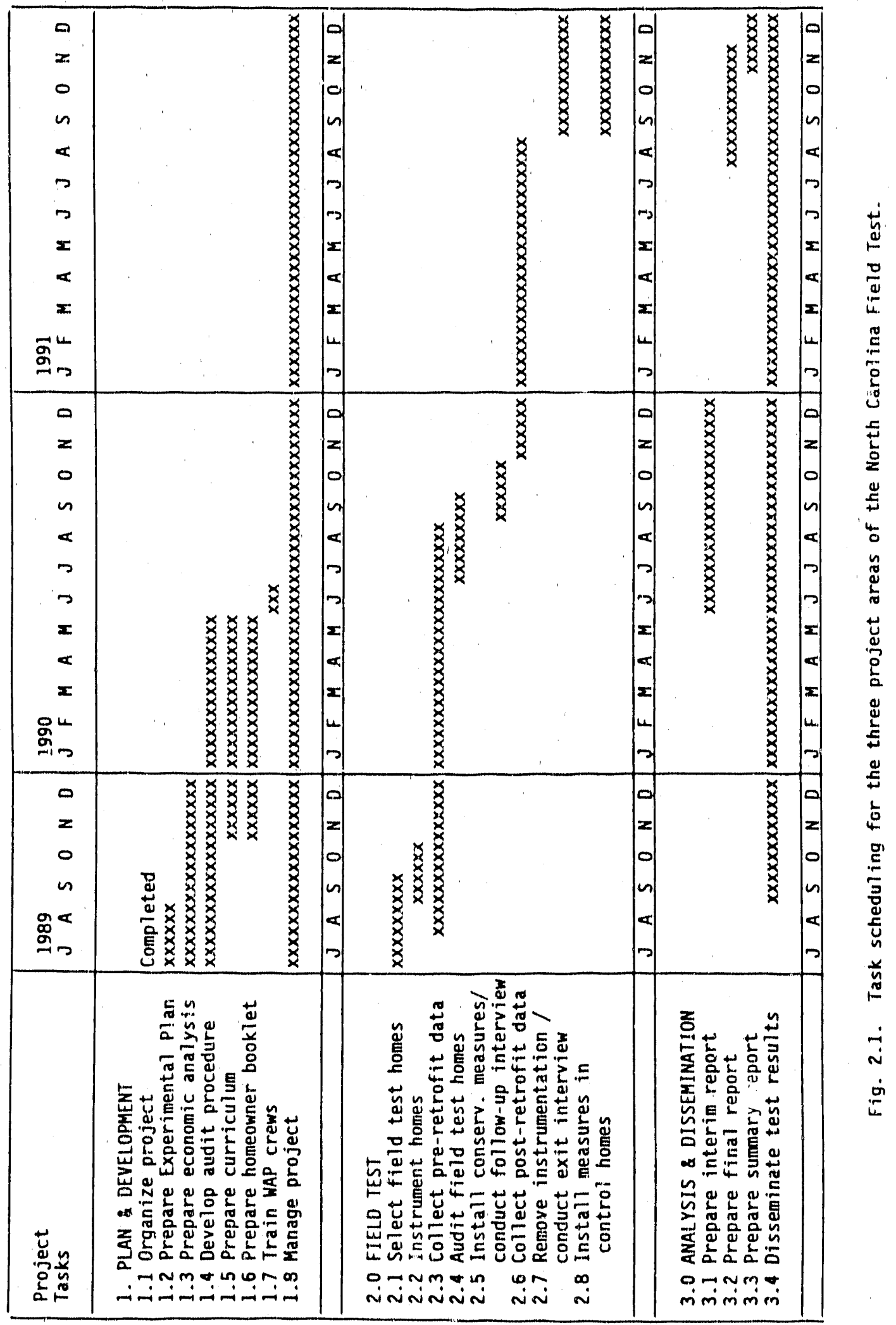


1.2 Prepare Experimental Plan. The Experimental plan is a detalled plan of how the profect, and particularly the fleld test, will be accomplished. ORNL prepared the plan which detalis the test design, particlpant roles, instrumentation needs and installation, required fleld data and collection methods, and data analyses. This report, the Experimental Plan, was completed in August 1989.

1.: Prepare Economic Analysis - The ASE will prepare a report detalling how to use economic analysis in a weatherization audit. This report will provide important analysis methods that w1ll be used by ORNL in completing the fleld Test Audit. Completion of this tast is scheduled for December 31, 1989.

1.4 Develop Audit Procedure - ORNL will develop the Fleld Test Audit with emphasis on hot and humld climate measures and will incorporate recently proven new weatherization measures and techniques. Scheduled completion of the audit is during the pre-weatherization test period on May 31, 1990.

1.5 Prepare Audit Training Curriculum - The ASE will prepare an audit training currtculum which will describe the objectives, activities, and the resources for training of weatherization crews to aid in collecting audit data and using the new weatherization audit. Completion date for this is May 31 , 1990.

1.6 Prepare Homeowner Booklet. The ASE will prepare a homeowner booklet which w11l describe the importance of auditing, what an audit and weatherization can do for the homeowner, and how the homeowner can achieve the most savings from weatherization. The booklet will be prepared concurrently with the auditors training curriculum and completed at the same time, May 31, 1990.

1.7 Train WAP Crews - Both ORNL and the NC-DECD will assist in training WAP crews. ORNL will instruct the NC-DECD on performing the Field Test Audit and they in turn will train the individual weatherization crews through workshops. Training will likaly include using blowex doors, installing new measures (such as radiant barriers), and conducting heating system diagnostics (such as flue gas analysis). Training of WAP crews should be completed in June 1990. 
1.8 Manage Profect and Provide Technical Assistance - The NC-DECD w111 manage the fleld test and assist the WAP providers as needed. ORNL w111 provide technical assistance to the NC-DECD and the NCAEC. The ASE will assist the DOE WAP by conducting briefings and making profect recommendations. This task will be distributed over the duration of the project.

\section{Field Test}

2.1 Select Fleld Test Homes. The NC-DECD w1.11 select test homes based on the criteria in the Experimental Plan (refer to Section 4). Particlpating WAP providers will assist by identifying homes in their service areas that qualify for the fleld test. The scheduled completion of this task is september 30 , 1989, blat enough test houses w1ll need to be identified by July to allow the type and number of metering needed for the test to be estimated.

2.2 Instrument Homes - The ORNL and the NCAEC will support this task. ORNL will provide instrumentation and technical assistance to NCAEC regarding installation. NCAEC will provide additional instrumentation and will coordinate the installation of all instrumentation. Instrumentation installation is scheduled to be completed by October $31,1989$.

2.3 Collect pre-retrofit Data - The NC-DECD will coordinate collection of entrance interview data on the house and occupants (August through October 1989). The NC-DECD will also coordinate collection of weekly monitored data, starting November 1, 1989. Pre-retrofit data will be delivered to the NCAEC for computer entry. The NCAEC will forward the data, as files on floppy $\operatorname{disk}(s)$, to ORNL for further processing. Preweatherization data collection w111 end on August 31, 1990.

2.4 Audit Field Test Homes - Following the pre-weatherization monitoring period, 40 homes will be audited using the Fleld Test Audit (treatment group 1), 40 homes will be audited using the current North Carolina WAP procedure (treatment group 2), and 40 homes will be audited using both procedures (control group) between July and September 1990. The weatherization audits will he conducted by the three weatherization providers. 
2.5 Install Conservation Measures / Conduct Follow-Up Interview - The 11 cal WAP providers w1l. install conservation measures according to the results of the audit procedure used for each of the 80 homes $1 r$ the two treatment groups. Installation will occur at the end of the pre-weatherization monitoring period between September and October 1990. At the same time, the NC-DECD W111 coordinate the assessment of the installed measures (measures installed, costs, and quality) and the collection of follow-up interview data.

2.6 Collect Post-retrofit Data - The NC-DECD will coordinate collection of post-retroflt weekly monltored data. The data will be delivered to the NCAEC for computer entry and forwarding to ORNL. ORNL will process the monitored duta which will include error checking, and processing into a final storage format. Post-weatherization data collection will occur between November 1 , 1990 and August 31, 1991.

2.7 Remove Instrumentation / Conduct Exit Interviews - At the conclusion of the monitoring, the NCAEC will remove and return instrumentation as needed. This includes collection of and returning the indoor tempexature sensors to the ORNL. At the same time, the NC-DECD will coordinate exit interviews of each household. These should take place between September and December 1991.

2.8 Install Meusures in Control Homes - For their participation in the project, the WAP providers will weatherize the control homes following test completion using the measures recommended by the most promising of the two audit techniques. Weatherizing these homes will be done concurrently with the instrumentation removal and exit interviews between September and December of 1991.

\section{3,0 Analysis and Dissemination}

3.1 Prepare Interim Report - ORNL will prepare an interim report at the end of the pre-weatherization monttoring period. The report will describe work through the half-way point of the fleld test, including a list of the installed retrofits and a summary of the pre-weatherization energy consumptions. Scheduled completion is December 31, 1990. 
3.2 Prepare Final Report - ORNL will prepare the final report of the profect. The report w11l summarize both pre. and post-weatherization work and w111 detall the final results of the profect. Scheduled completion is November 30 , 1991 .

3.3 Prepare Summary Report - The ASE w111 prepare a summary report which will review project results and document policy and program recommendations based on these results. Scheduled completion for the summary report is December 31 , 1991.

3.4 Disseminate Test Results - The ASE, the ORNL, and the NC-DECD will participate in dissemination of test results through presentations at appropriate conferences/meetings, publications, and by assisting other participants in preparing information for public releage. This is an ongoing effort throughout the duration of the project. 


\section{CONSERVATION NPPROACHES}

\subsection{NORTH CAROLINA'S CURRENT LOW-INCOME WEAIHERIZATION ASSISTANCE PROCRAM}

North Carolina's current weatherization program is limlted to seven weatherization measures that are installed based on thetr prioritized ranking. The measures are ordered relative to their percelved cost-effectiveness, The measures in order of their priortization are:

(1) Infiltration measures,

(2) attic insulation,

(3) water heater, pipe, and floor insulation,

(4) duct insulation,

(5) underpinning (anclose the crawl space),

(6) sturm windows, and

(7) stcrm doors.

Each measure is instalied in order of priority until the aliotted funds, up to $\$ 1400$ per house on average (including administration costs), is expended or the next consecutive measure is unaffordable within spending limits. A higher priority measure must be fully installed before the next measure is considered.

Infiltration measures include caulking, adding new weatherstripping and replacing existing defective weatherstripping around windows and doors, repaling or replacing windows and doors in poor condition, and repalring holes in walls and floors. The ldentfication of inflitration deficlencles and locations is made visually. Attic insulation is installed to a minimum of R-19 and a maximum of R-30. Attic insulation is installed in conjunction with installing appropriate attic vapor barriers and attic ventilation.

All uninsulated electric water hoaters recelve a water heater insulation wrap. Wrapping of fuel-fired water heaters is permissible. Hot water plpes and heating duct are also insulated. Houses with a crawl space recelve floor 
insulation or urderplnning depending on the helght of the orawl space. The remalning measures, storm windows and doors, generally have a much longer payback and therefore are installed only on a limited basis.

\subsection{THE FIELD TEST AUDIT}

The Fleld Test Audit is being developed by the ORNL. The ASE is assisting in tes development by providing recommendations on using economic analyses for measures selection. The new audit will be computerized to provido an easier, faster, and more accurate evaluation of the most appropriate measures for an individual house. Thi's should substantially reduce the computational time normally required to evaluate specific measures. The new audit will have several features beyond traditional weatherization approaches. In addition to traditional measures, the Fleld Test Audit will Include:

(1) new weatherization techniques and measures that have been found to improve current practice and of ten have attractive paybacks, such as blower-door gulded inflitration reduction, radiant barriers, and hcating equipment replacements,

(2) a procedure for selecting weatherization measures based on costeffectiveness as related to the characteristics of the individual house,

(3) a method of evaluating the interaction of measures in the measure selection process, and

(4) an analysis of measures for reducing space cooling energy use.

By Incorporating these features, the new audit will offer additional attractive weatherization measures and an improved basis for measures selection that will hopefully improve the overall cost-effectiveness of weatherization. 


\section{FIEID TEST DESIGN ANU IMPLERGENTATION}

\subsection{EXPERIMENTAL DESIGN}

One-hundred twenty houses meeting the eligibility requirements ldentified in Section 4.2 will be selected and weatherized according to a one-way classification design with three treatments. The primary factor of interest is the method used to select the weatherization measures for an individual house. The three levels of this factor (treatments) that will be tested are (1) measures selected by the North Carolina Field Test Audit (treatment 1), (2) measures selected using the procedures currently used in the North Carolina WAP (treatment 2), and (3) a control group in which no measures are installed. The 120 houses will be selected according to the procedure described in section 4.3 and assigned to the three treatment groups according to the randomized procedure identifled in section 4.4. With this design, differences between treatment effects can be identifled using a one-way analysis of variance. ${ }^{5}$

Pre- and post-weatherization testing will be used to determine the energy savings of the individual houses and, from these, the average savings of the treatment groups. Pre-and post-weatherization testing allows the houses to serve as thelr own reference and, thus, allows individual house savings to be determined. Pre and post-testing is useful in conservation program evaluations where an on-off design cannot be employed, which is the case for this fleld test. The on-off design may be used whenever a system can be turned off so that the bullding operates as if the conservation measure had not been installed. 6

\subsection{HOUSE ELIGIBILI'TY}

Houses included in the study population will be limited to those with the following characteristics:

1. The house must be located in the counties in which the WAP is administered by the three providers identified in Section 2.1 to centralize the project and to $11 \mathrm{mlt}$ the number of agencies involved. 
2. The house must be a single-family detached structure, but not a mobile home. Less is known of multifamily structures and mobile homes, both of which can be studied later.

3. The house must be heated during the winter primarily by natural gas, propane, kerosene, or fuel oil systems that are currently in operating condition. Secondary fuels (such as wood) or heating systems (such as portable kerosene and electric heaters) must not be used to substantially heat the house (use limited to half a day per week or in bathrooms). A survey of houses recently weatherized under the WAP in the field test service area indicated that heating systems other than the four identified were not sufficiently prevalent to warrant including in the study population (their inclusion would lead to increased variability between the houses and increased costs for the monitoring equipment). Additionally, the Field Test Audit may not be applicable to these other types of systems. Accurately measuring the amount of secondary fuel used to heat a house is difficult. Thus, extensive use of secondary fuels or systems increases the uncertainty of energy use determinations and can make such determinations impossible.

4. The house must be cooled during the summer by only one or two electric window air conditioners that are currently in operating condition. Two goals of the experiment are to determine the performance of an audit that includes conservation measures specifically designed to reduce cooling energy use and to determine the cooling energy savings achieved under the current WAP. Prior experience has indicated that most low-income houses, if air conditioned, are cooled by window air conditioners and that the use of more than two units per house is not sufficiently prevalent to warrant including in the study population. 7

5. The house's potable water must be heated with electricity. The survey discussed above indicated that this is the most common type of water heating system in the service area. Inclusion of other systems would significantly alter the instrumentation approaches to be used to monitor the water heating and heating system energy consumptions. 
6. The house must not be scheduled to receive conservation measures under any other weatherization program to help ensure that the only changes made to the houses during the testing period are the treatments identified in Section 4.1.

7. The occupants must be eligible for North Carolina's WAP at the time of being included in the test. A primary goal of the experiment is to determine if the audit procedure can significantly increase the energy savings and costuffectiveness of state low-income WAPs.

8. The house must be occupied by the owner. Renters may be more likely to move during the experiment than homeowners. Test houses in which the occupants move will have to be dropped from the study due to changes in energy use that can resuit from a change in occupancy. Dropping houses from the study should be avoided, if possib?e, to maintain the integrity of the experimental design.

9. The occupants must currently be paying their own fuel and electric bills and have regularly paid their bills in the past. The energy use behavior of people who pay their own energy bills may be different from those who do not pay them or have them paid through a relief program. Therefore, the performance of the conservation measures and selection methods in these houses may be different.

10. The occupants must not be planning an extended stay away from the house during the monitoring period, although 1-2 week vacations are acceptable. The energy consumpiions of houses in which the occupants are away for an extended time period may be difficult to analyze using currently developed analysis techniques. In these homes, there may be insufficient data collected to characterize the house when it is occupied.

Narrowing the population of houses to those with these characteristics will al. Low more definitive results on the most common type of low-income houses in the service area, help ensure that the goals of the experiment are met, and make it easier to develop equivalent treatment groups. 


\subsection{SELECTION PROCEDURE}

Because all the houses in the population of interest could not be studied, a sample of 120 houses representing the pcpulation will be chosen. This sample size was selected baset on cost considerations and the number of treatment groups desired. Treatment group sizes were determined based on the expected error in estimating average house energy savings from weatherization.

Selection of the 120 houses will be performed by identifying individual houses conforming to the selection criteria, determining if the occupants are willing to participate in the field test, and accepting them if they consent until the 120 house quota is reached. This quota sampling approach was chosen because a more formal statistical technique such as random sampling will require time and funds that are not avallable. (In this latter approach, a much greater number of eligible homes than needed would have to be identified, and then 120 houses selected randomly from the developed 1ist.)

The selection of houses should proceed in three steps:

1. Low-income households that may be eligible under North Carolina's WAP and that are in the counties served by the three providers participating in the fileld test need to be identified using any avallable resource. Possible resources include (a) lists of homes potentially eligible for the North Carolina WAP, North Carolina fuel assistance program, or utility troubled payment programs, and (b) outreach efforts by outreach workers.

2. Information on each of the houses as they are identified should be collected to determine their eligibility for the field test. A form similar to that shown in Fig. 4.1 ("North Carolina House Screening Checkiist") could be used for this purpose. This checklist covers criteria 2-10 identified in Section 4.2. Information needed to complete the checklist can be obtained through client interviews (in person or over the telephone), house inspections, and income verifications. 
3. The occupants of the houses eliglble for the fleld test should be provided with a copy of the fleld test summary ("North Carolina Demonstration Project") shown in Fig. 4.2. If they are interested in participating in the field test, then the "Household Agreement Form" in Fig. 4.3 should be completed and forwarded to the person maintaining the field test files. The houses should be numbered sequentially from 1 to 120 as they are accepted into the field test.

\subsection{ASSIGNMENT PROCEDURE}

In order for the comparison between treatment groups to be valid, the three groups must be similar or equivalent. The 120 houses will be assigned to the three groups ( 40 houses to a group) at the end of the preweatherization period using a randomized procedure with stratification to ensure uniformity between groups. The assignments will be made after the pre. weatherization period to minimize the effect attrition will have on creating unequal groups. A procedure without stratification could be employed, but this method becomes progressively more unreliable as the number of houses becomes smaller. The strata to be used involves using two key variables that can significantly affect house energy use and the energy savings that might be achieved by the audit or current selection practice. The first variable, the type of heating system installed in a house, is important because systems are controlled differently and the way they deliver heat also differs. Additionally, conservation measures selected by the audit for a given house will likely depend on the house's heating system due to hardware and cost considerations. The second variable, the number of working air conditioners installed in the house, may affect the total cooling energy use from a capacity viewpoint and the manner in which the units are operated. 
NORTH CAROLINA HOUSE SGREENING GHEGKLIST

Name: Phone number:

Address :

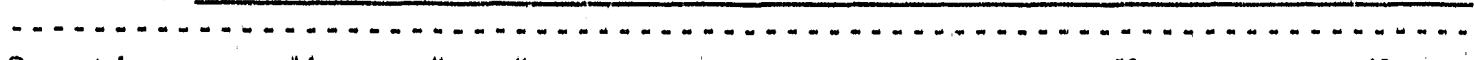

Questions needing a "yes" answer

Yes

Is the household eligible for North Carolina's

Low-Income Weatherization Assistance Program?

Is the home a single-family detached house, but not a mobile home?

Is the house occupled by the owner?

Is the house heated primarily by fuel oil, natural gas, propane, or kerosene systems? (circle fuel)

Is the house air conditioned by only one or two electric window air conditioners? (circle\#)

Is the primary heating system and at least one air conditioner in operating condition?

Is the house hot water heated by electricity?

Do the occupants currently pay their own fuel and electric bills and have they regularly paid them in the past?

Questions needing a "no" answer

Is the house scheduled to receive conservation measures under another weatherization program?

Do the residents have any plans to move or be away from the house for an extended time period during the testing period (normal vacations of 1-2 weeks are acceptable)?

Is a secondary fuel (such as wood) or heating system (such as portable kerosene or electric heaters) used more than half a day per week to heat areas other than the bathrooms?

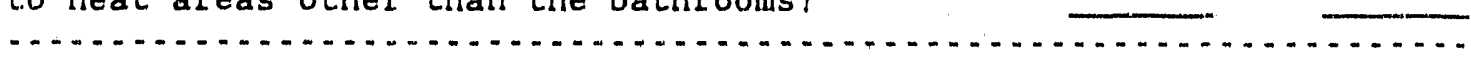
If questions needing a "yes" answer are answered yes and the "no" questions are answered no, the house is eligible for the field test.

Is this house eligible for the field test? Completed by: Yes

Fig. 4.1. North Carolina house screening checklist. 
NORTH CAROLINA DEMONSTRATION IPROJECT

The North Carolina Departaunt of Economic and Community DevelopmentEnergy Division, invites you to take part in a special demonstration project that will weatherize your home free of charge!

The demonstration profect will evaluate diffexent methods of selecting conservation measures to be installed in houses under the state's Weatherization Assistance Program. To evaluate the different methods, we will install conservation measures as recomended by the different methods in selected hoines in counties in aastern North Carolina. Each of the houses will be equipped with small meters to measure energy use. By comparing the home's energy use before and after the weatherization, we will determine how much energy is saved.

All of the weatherization measures to be installed have been evaluated previously and are safe and reliable. Several of the measures are routinely installed under the state's current weatheriaation program. Although we know that these measures reduce heating bills, we do not know how much cooling bills are reduced, Other measures may be recommended by a new selection method that we want to test. These measures may be specifically designed to reduce cooling energy consumption, or they may reduce both heating and cooling energy use. The actual savings obtalned from the measures that may be recommended by the new selection method are not known. Thus, we need to find out how well the measures work in the North Carolina area.

The state of North Carolina is conducting the field test in cooperation with the following organizations:

1. Franklin/Vance/Warren Opportunlty, Johnston-Lee Community Action, and Four-County Community Services - local providers of the state's Weatherization Assistance Program,

2. North Carolina Alternative Energy Corporation - a state non-profit research organization working with electric utilities in North Carolina to improve energy efficiency,

3. The Alliance to Save Energy - a national non-profit organization working to Improve our nations's energy efficiency, and

4. Oak Ridge National Laboratory - a government-owned national research laboratory providing research and technical assistance to the profect.

If you decide to participate in the demonstration project, the following will occur:

Fig. 4.2. Sumary of the North Carolina Field Test for participating households. 
1. Th1s summer, techniclans will Install a few small, simple meters outslde your house to monftor its energy use. A new wirlng circult may be installed to your alr oonditioners and hot water system (the clroult may be run around the outside of your house in condult). An electric meter will be installed in the new clroults to monitor energy use of these appliances. An added benefit of new circults is that they may upgrade and improve your current wiring system. A different type of meter will be installed to monitor the energy use of your heating system. In addition, a small meter about the size of a paperback book (about $6 \times 2 \times$ 4 inches) will be placed in the living area of your house to monitor the indoor temperature.

2. Weatherization measures will be installed in your home in the fall of 1990 or 1991. Before the measures are installed, an energy auditor w111 visit your house and collect information about your home, test the efficiency of your heating system, and find out where heat leaks out of your home using a special fan placed in your front door.

3. Energy use data will be collected from your house from November 1989 unt11 october 1991. Once a week, a technician wlll read the meters installed outside your house. Once a month, the technician will read the meter installed inside your house, Once or twice a year, a techrictan will collect other data on your house using special instruments.

In return for particlpating in the demonstration project, the following assurances are made:

1. Weatherization measures will be installed in your house by the weatherization provider serving your area. There will be no charge to you for these services. We will pay for the full cost of the weatherization materials and labor. (You will still be responsible for paying your oum fuel bills, however.)

2. All the information collected about your house will only be used for research purposes and will remain confidential. No information regarding you will be released without your prior approval.

This is an important research study that will help us learn how to Improve our weatherization program and better control home energy costs. Your particlpation in the study will make a big contribution to realizing these objectives. If you decide to participate in the demonstration program, please read, fill out, and sign the Household Agreement form.

Fig. 4.2. (continued) 
HOUSEALOLD AGREBEIENT FORM

I.

reslding at

(homeowner's name)

(street address)

(clty, state, and zip code)

agree to particlpate in the demonstration profect described by the North Carolina Demonstration Profect sheet. I agree to

1. allow the local watherization provider to release information on my home's energy use to reseavchers so that they can conduct their evaluation:

2. provide researchers, energy auditors, and weatherization technicians access to my home during reasonable hours (a staff person will phone me to schedule these times) during the demonstration;

3. answer interview question and allow my house to be audited and weatherized using selected conservation measures;

4. allow techniclans to install, maintaln, and remove small energy use meters inside and outside my home;

5. allow techniclans access to my property to read meters; and

6. make every effort to safeguard the small meters installed inside and outside my home to monitor indoor temperature and energy consumption.

I understand that the demonstration profect will be conducted in two parts, which means that my house will be weatherized in elther the fall of 1990 or the fall of 1991.

(homeowrier's signature)

(date)

Fig. 4.3. Household agreement form. 
The asslgnment of the 120 houses to the three troatment groups will be performed in thiee steps:

1. The type of heating system and number of als conditioners will be determined for each house. This information can be collected at the time the "North Carolina House Screening Checklist" is fllled out by clrcing the correct aholoes in the fourth and fifth questions. This information w111 also be gathered as part of the survey data.

2. The houses will be classifled into one of the following elght strata: natural gas heating system with one alr conditioner, natural gas heating system with two alr condltioners, propane heating system with one afr conditioner, propane heating systam with two alr conditioners, oll heating system with one alr conditioner, ofl heating system with two air conditioners, kerosene heating system with one alr condltioner, and kerosene heating system with two alr conditioners.

3. A third of the houses in each of the elght strata will be randomly assigned to each treatment group. In this way, the same number of houses that have natural gas heating systems and one alr conditioner, for example, will be assigned to each of the three treatment groups, making the groups similar with respect to the chosen varlables. 


\section{DATA PARAMGTERS AND MONTTORING INSTRUMENTATION}

The data to be collected for this fleld test correspond to the minimum data set spectfled in Ref. 4. The data to be collected can be divided into two types: survey data and time-sequential data. The survey data are simflar to audfteype data in that they are essentially all collected by point-in-time measurements. The survey data typlcally include desoriptive detalis of the house construction and 1 ts mechanlad system(s), short-term performance evaluations of the bullding shell and/or mechanical system(s), and detalls of occupancy levels and patterns. The timesequential data are recorded on a continual basis. Primarlly, this includes energy consumption data, indoor temperature data, and outdoor temperature and other weather. related data. Weatherization providers, under NC-DECD direction, w111 collect a11 survey and time-sequential (continuous) data. The time schedule for data collection is presented in Fig. 5.1.

\subsection{SURVEY INFORMATION}

The fleld test will require the following survey data:

1. entrance interviow information,

2. follow-up and exit. lnterview information,

3. house shell and mechanical system performance information, and

4. weatherization measures listing and installation quality verification.

Collection of survey data will be the responsibility of NC-DECD with ORNL providing technical assistance.

The entrance interview is used to collect house and systems descriptive Information summarizing the physical characteristics of the house, 1 ts mechanizal systems (heating, cooling, water heating, etc.), and how the house is accupled. This information is needed to (1) assess the dependency of energy use on these factors, (2) document the house description for future 

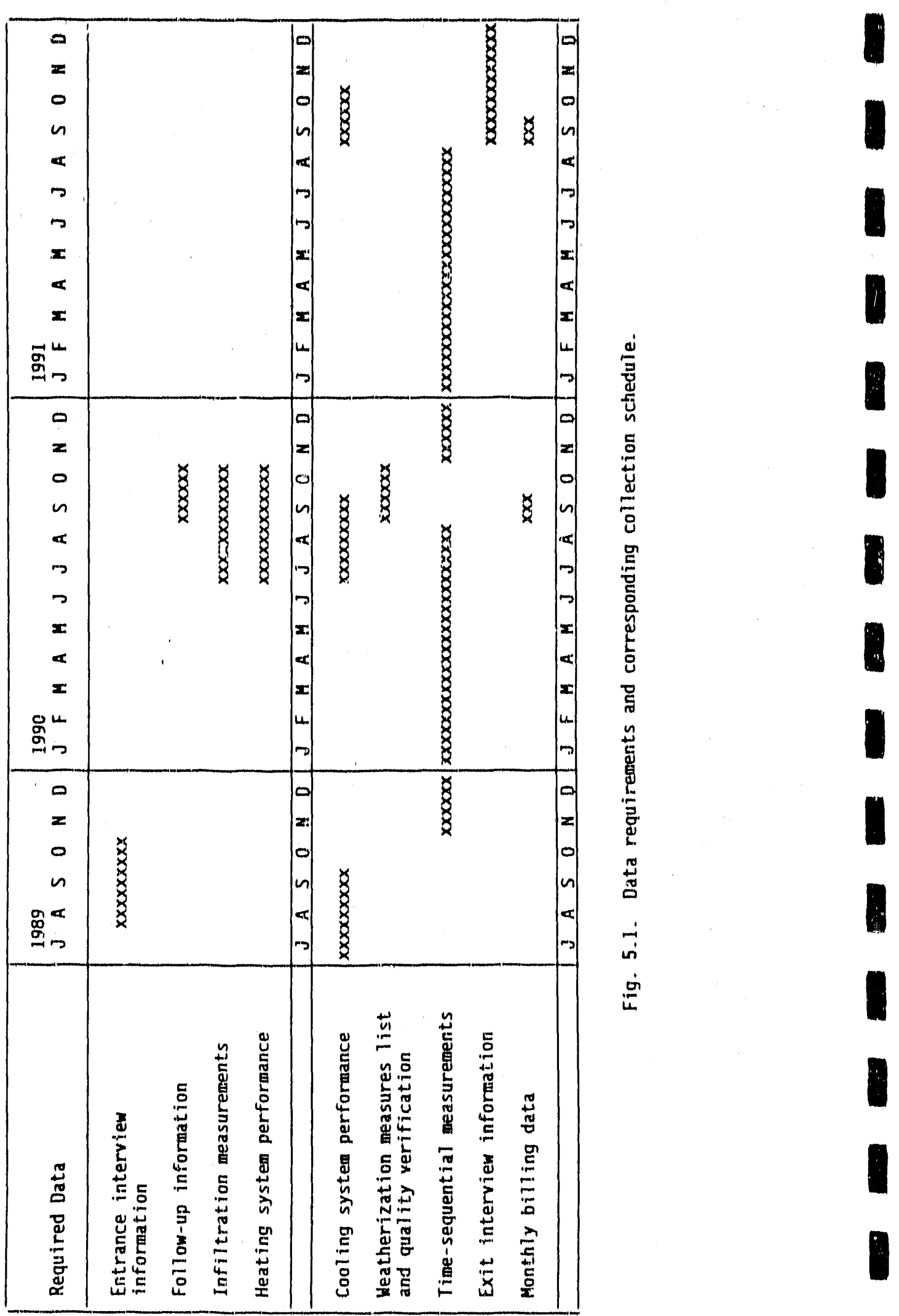
referonoe, (3) allow teat resulta to be comparad whth other houses having almilar oharaoteristios, and (4) dooument the oharactariatios of the houge and Lts occupants to which the results relato. Tablos 5.1 through 5.311 st the general information types raqufred for the survey data. The Survey Intarvlaw Form in Appendix A should be used to record the entrance intervlow data. Entrance Interviaws should be conducted between August and October of 1989.

Follow-up and exit Interviow information will be used to halp identefy any changes that have occurred during the testing that could sigrificantly affect results. Table 5.4 11sts the general information types in the follow. up and extt interviews. This information will consist primarily of 1dentifying changes to the data oollected on the survey Intarviow form. Follow-up interviews should be scheduled during the instaliation of veatherization meusures (September to datober 1990). Exit Interviows should be scheduled during ingtrumentation removal (September to December 1991).

The house shell assessment consigts of inflitration measurements to determine the alr "tightness" of the bulldirg both before and after weatherization. These measurements can be used to (1) provide an indicator of the integrity of the bullding shell, (2) characterize secondary inflltration reductions thut occur indireotly from another shell measure such as added wall insulation, and (3) provide an indicator that may be useful in any future study of the test results. Infiltration measurements should be performed using the blawer-door fan-pressurization technique. 8,9 The technique essentally measures infiltration into and out of a house by depressurizing and pressurizing the interior space between 10 and 60 pascals $(0.04$ to 0.24 in. $\mathrm{H}_{2} \mathrm{O}$ ) below and above amblent outdoor pressures. Infiltration measurements should be made just before ard immediately after weatherization (between July and October 1990). If possible, the measurements can be made when the houge is being audited or. weatherized.

The performance of mechantcal systems should also be assessed. Air conditioner ( $A C$ ) operation should be verlfied during each suminer (July through September of 1989, 1990, and 1991). Window air conditioners can be checked for operation by measuring and comparing the indoor $A C$ exhaust alr temperature and the indoor room air temperature. The AC exhaust alr temperature should be 
Table 5.1. House desortptive infarmation.

General

House Location

House aketch, plan vlew

House and roof type

House atyle

House foundation type

Rnof and external wall colors

Percentage of each floor heated and cooled

No, of floors

Insulation

Location and area

Insulation type and thickness

Construstion

Percentage of bottom floor carpeted

Windows, glass doors, and non-glass external doors

Area measurements per external wall facing

Nurber of window panes and storm windows

Non-glass door type

Major appliances

Domestio hot water system

Type

Location

Hot water temperature

Nameplate (rated) Information

Blanket thickness

Other major appliances

Type

Fue 1

Location per type 
Table 5,2. Space conditioning systems desoriptive information

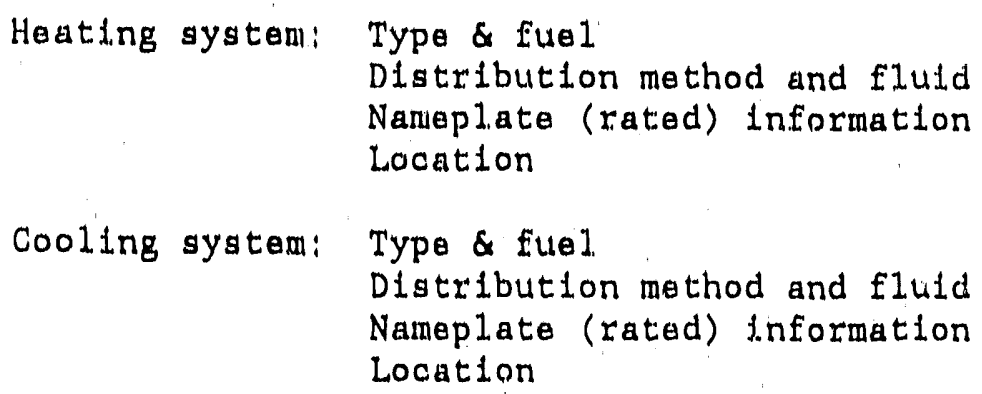

Table 5.3. Entrance interview information.

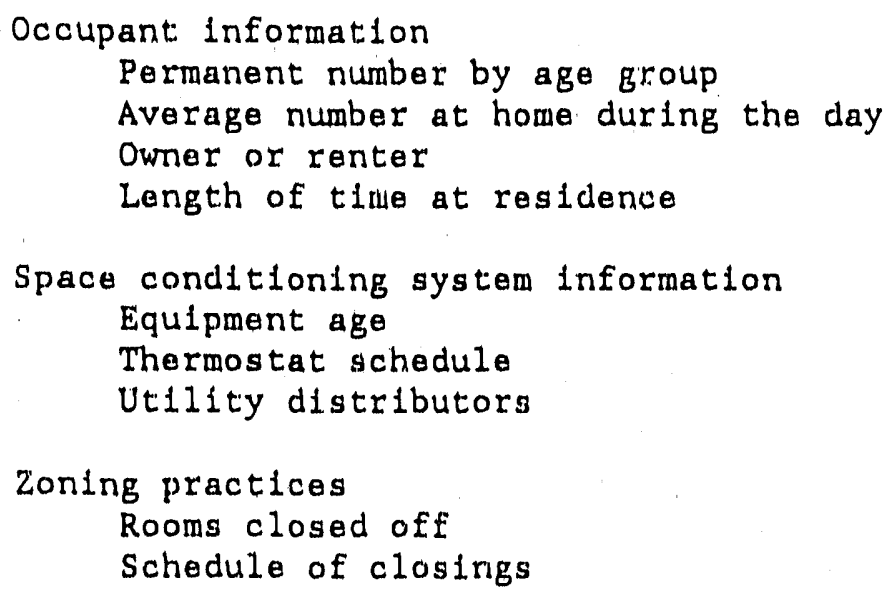

Table 5.4. Follow"up and exit interview information

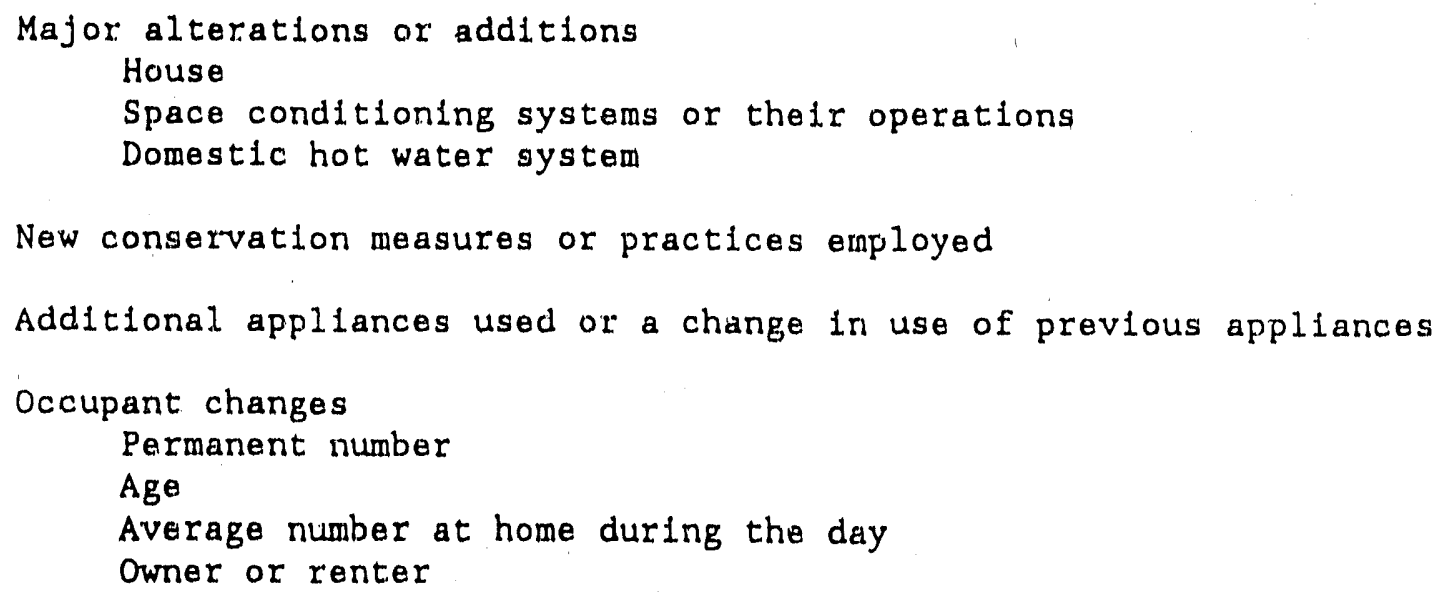


at least $10^{\circ} \mathrm{F}$ lower than the room afr temperature. The performance of space heating systems should be evaluated to verify that the heating systems ace functioning properly and to determine operating efficiencies. Heating system assessment will consist of a visual check and a flue gas (efficiency) analysis for each unit. Heating system tests should be done on all houses during the auditing or weatherization periods (July through October 1990). Houses that receive a furnace tuneup or replacement as a conservation measure should have two, before and after, efficiency checks.

The remaining survey information is collected at the time the weatherization work is 1\%upected. A list of installed measures and the individual costs of each measure should be prepared. The weatherization work is evaluated to assure that the work meets specifications and to assess the general quality of the installation. The installation assessment can be by visual inspection where pnssible or by measurements if needed (such as measuring attic insulation depth). If the installation is below specifications, correction should be made prior to the beginning of postweatherization testing. Thus, installation checks will need to be done concurrently with weatherization installations (September and October 1990).

\subsection{TIME-SEQUENTIAL MEASUREMENTS}

Four energy use parameters will be measured continuously for each test house: total electricity use, space heating energy use, air conditioning electricity use, and water heating electricity use. The average indoor temperature will be monitored continuously in each house. Weather parameters will be monitored continuously using three weather stations. The timesequential measurements will be made over the entire pre- and postweatherization periods. The monitored parameters along with pertinent information relative to each are summarized in Table 5.5.

NCAEC, with utility assistance, will provide all watt-hour meters (for metering electricity for house total, air conditioning, and water heating energy uses) and select the brand and type of these meters. NCAEC will provide for calibration of each watt-hour meter. NCAEC will also acquire vapor meters for monitoring propane use and supply run time meters for 


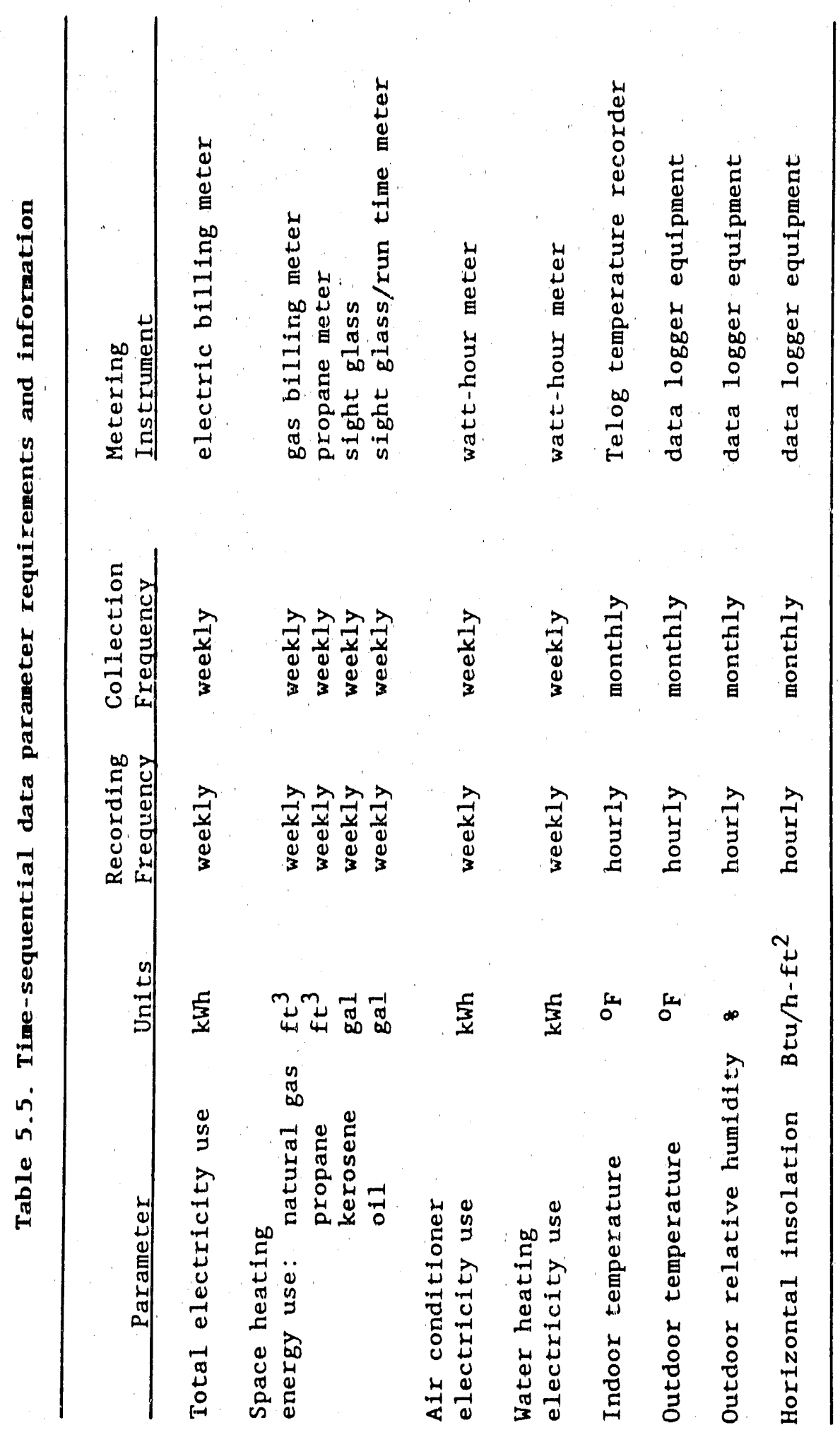


metering oll consumption. ORNL will provide kerosene metering systems, indoor temperature devices, and weather data instrumentation. NCAEC will handle installation of all instrumentation. ORNL will provide technical assistance for instrument installation and will assist in the setup of weather stations.

\subsubsection{House Total Electricity Use}

House total electricity use will be measured continuously by the watthour meter that records whole-house electricity use for the servicing utility. House total electricity use will be manually read and recorded on a weekly basis. Meters should be accurate to within 38 over the duration of the project.

The standard billing data for each house should be acquired by the NCAEC from the accounting records of the servicing utility. Billing data should be collected and then forwarded to the ORNL at two times, the ends of the preand post-weatherization monitoring periods (September 1990 and September 1991).

\subsubsection{Space Heating Fuel Use (natural gas, propane, kerosene, and oil)}

A previous survey indicated that the majority of houses served by the Weatherization Assistance Program in the Raleigh area use natural gas, propane, kerosene, or fuel oil for space heating fuel. As a result, testing will be limited to homes using one of these four heating fuels. Fuel use will be measured continuously and recorded on a weekly basis.

Natural gas use should be read from the utility gas meters located at each house. NCAEC will be responsible for having utility gas meters calibrated to provide accuracy within 38 .

Since propane is usually sold to customers as a bulk liquid (like oil and kerosene), vapor meters are not typically installed at residential sites. Therefore, vapor meters will have to be installed at each house using propane 
fuel. Meters should be located adjacent the house in the propane supply line just before tit enters the house. NCAEC will be responsible for acquiring and insuring the accuracy of propane meters to within 38 .

Instead of using a flow metering device (as inftially planned), kerosene use will be measured using a sight glass installed at the storage tank on the fuel supply line. The ORNL will design a low-cost sight glass indicator for kerosene systems since a universal, easily-installed, off-the-shelf unit was not found. Consumption will be monitored by simply recording the tank level on a weekly basis and relating level changes to tank volumes. ORNL will procure all parts and supply them along with assemlily and installation procedures to the NCAEC who will coordinate installation.

Fuel oil consumption will be measured using a sight glass (for above ground tanks which are the most abundant) or a run time meter (for below ground tanks). The run time meters are used to measure the on-time of the pump in the oil supply line. This pump turns on with the furnace and normally provides a relatively steady flow such that run time will provide an accurate measurement of oil consumption, ORNL will provide calibrated oil nozzles for pumped oil systems. The calibration will provide an oll consumption rate relative to the run time of the pump. NCAEC will be responsible for installation of the calibrated oil nozzles and run time meters.

\subsubsection{Air Conditioner Electricity Use}

Each house will have one to two window air conditioners. Air conditioner electricity use will be measured using a watt-hour meter. Watt-hour meters should be installed on a wall outside the house near the electrical panel box which houses the breakers that supply power to the air conditioner(s) if outdoors or a more suitable location as determined by the NCAEC. If desired, a new circuit(s) enclosed in approved outdoor conduit may be run outdoors along the wall of many houses to a new receptacle at each window air conditioner. Electric meters, should be accurate to within 38 over the duration of the project. 


\subsubsection{Water Heating Electricity Use}

Each house will have electric water heating. Water heating electricity use will be measured using a watt-hour meter. Watt-hour meters should be installed on a wall outside the house near the electrical panel box which houses the breakers that supply power to the water heater if outdoors or a more suitable location as detexmined by the NCAEC. If desired, a new clrcuit enclosed in approved outdoor conduit may be run outdoors along the wall of many houses to the water heater. Measurement accuracy within 38 is also needed.

\subsubsection{Indoor Temperature}

The indoor temperature of each house will be monitored using Telog's 2103 Ambient Temperature Recorder (specifications are provided in Appendix B). These devices include a temperature sensor and microprocessor-based electronics to calculate and store the average hourly temperature and have been found (through testing) to be accurate to within $1^{\circ} \mathrm{F}$. During the summer periods, previous work has shown that the device should be located in the room having the window air conditioner. ${ }^{7}$ If two air conditioners are present, the device should be located in the room with the air conditioner that best typifies the temperatures in the main living area of the house. During the winter, the device may have to be relocated if another area best typifies the wintertime temperatures in the main living area of the house. The placement of the device should minimize its exposure to radiant energy from the sun, exterior walls and windows, lamps, and other significant radiators. The device should also not be exposed to heat or cold sources such as vents or appliances in the surrounding area. Temperature recorders will be provided by the ORNL and installed by the NCAEC.

\subsubsection{Ambient Weather Parameters}

Four weather parameters will be measured at each of the three weather stations: outdoor temperature, relative humidity, insolation, and wind speed. Weather data will be recorded using a Campbell Scientific Model 21X Data Logger (specifications are provided in Appendix B). The data logger will 
record weather parameters continuously and store hourly averages on cassette tape. The NCAEC will select the sites for and set up the three weather stations. ORNL will provide the weather station components and assist in their set up.

The weather station instrumentation w11l consist of: a battery powered data logger, a battery powered tape recorder, a type $T$ (copper-constantan) thermocouple, a humldity probe, a pyranometer, a radlation shield ( $s$ ), and a wind anemometer. Sensors should be compatible with the data logger and selected to provide measurement of outdoor temperature accurately to within $1^{\circ} \mathrm{F}$, humidity within $58 \mathrm{RH}$, solar radiation within $10 \mathrm{BTU} / \mathrm{h} \cdot \mathrm{ft}^{2}$, and wind speed within 108 .

The temperature and humidity sensors of the weather stations should be located where they are unaffected by heat sources or sinks in the surrounding area and where the ambient air is well mixed with the surrounding air. A sensor location on the north side of a building and below roof level is preferred. A radiation shleld should be used to protect the sensors from the sky and other significant radiation sources such as roofs, walls, driveways, patios, and the ground. The shield will also protect sensors from rain, hall, lightning, and other ambient conditions.

The pyranometer should be installed horizontally above the level of the roof, and in a position where nearby objects (houses, trees, poles, etc.) do not block radiation or reflect radiation to the sensor. Other meteorological equipment should be located below or north of the radiation sensor.

The wind speed indicator should be installed sufficiently above the level of the roof and away from any obstructions such as buildings, building contours (i.e., roof features), or trees that could disrupt the air flow at the sensor. 


\section{DATA MANAGEMERT}

Although all data will not orlginate in a computer-based form, all data will aventually be managed and processed using computer-based systems. Data bases will be designed to store information in separate flles. The links (relations) between separate flles w111 be house ID numbers and the dates and times of the time-sequential data. The data bases will contain all data flies In their final. form (all files have been checked for accuracy and corrected as needed). Characterization of data and statistical analyses will use the data from these files.

\subsection{SURVEY INFORMATION}

Survey information will be collected through interviews, site visits, and limited measurements using sheet data forms. The survey Interview form is shown in Appendix A. Some additional survey information will likely be collected as part of the Fleld Test Audit procedure being developed. The data from completed survey forms will be entered into a computer database using a ful.1-screen interactive data entry routine. The database system will be designed using the dBase III Plus Database Management Systell. * The system will display an image of each data collection form and will highlight the data entry areas. The operator simply types in a data value as it appears on the field data sheet. After a return, the data is automatically stored in the database and the cursor moves to the next data entry location. After all data on the display screen has been entered, a new form will appear for entry of the next sheet of data. This procedure is repeated until data for all houses has been entered.

ORNL will supply the database program to the NCAEC. The local weatherization providers will provide completed survey data forms to the NCAEC who will input the survey data to a computer. Once data entry is complete and the data has been stored in a data file, a copy of the data file should be put on a floppy disk and the disk forwarded to the ORNL. ORNL will do the final

\footnotetext{
*Iicensed software of ASHTON. TATE, Torrance, CA.
} 
data processing and storage. The flow of data processing for survey data 1s lilustrated in Fig, 6.1.

\subsection{TIME-SEQUENTIAL MEASUREMENTS}

Time-sequential data will be collected using sheet data forms and computer-based data loggers. Weekly readings from each house (total electriclty use, space heating fuel use, alr conditioner electriclty use, and hot water electriclty use) will be logged on the data form shown in Fig, 6.2. The local weatherization providers w1ll take the weekly readings and provide complated data forms to the NCAEC. NCAEC will handle this data the same way as survey information except that a different database program (also supplied by ORNL) will be used. Data files will be created using the automated database program and a copy of the data flles on floppy disk will be forwarded to the ORNL for processing and final storage. Since the electric and fuel use meters are totalizing meters, data processing will include subtracting past consumption data from the latest recelved to determine actual. weekly consumptions. Error checking, correction, and final storage of flles will be part of the ORNL processing routine.

Computer-based data loggers (Campbell Model 21X) w1ll be used to record weather data on an hourly basis. The data loggers have limited memory and therefore will be setup to write recorded data to cassette tape when the internal storage buffer of the logger is fllled. Monthly, local weatherization providers will collect the cassette tapes and provide them to NCAEC for forwarding to ORNL. ORNL will move the data from the tape to computer disk. The data will then undergo final processing and storage.

Indoor temperature data will also be collected by a computer-based logger, the Telog Model 2103 Recorder. Monthly, weatherization providers will transfer the hourly data from each logger using hand-held data transfer units (DTU's) provided by ORNL. Data from up to 60 loggers can be stored 1l, each DTU. The DTU is then exchanged for a new unit at the NCAEC who transfers the data from the filled unit to a computer using software supplied by ORNL. A disk(s) containing the temperature files is then forwarded to the ORNL where the temperature data will undergo final processing and storage. Six DTU's 


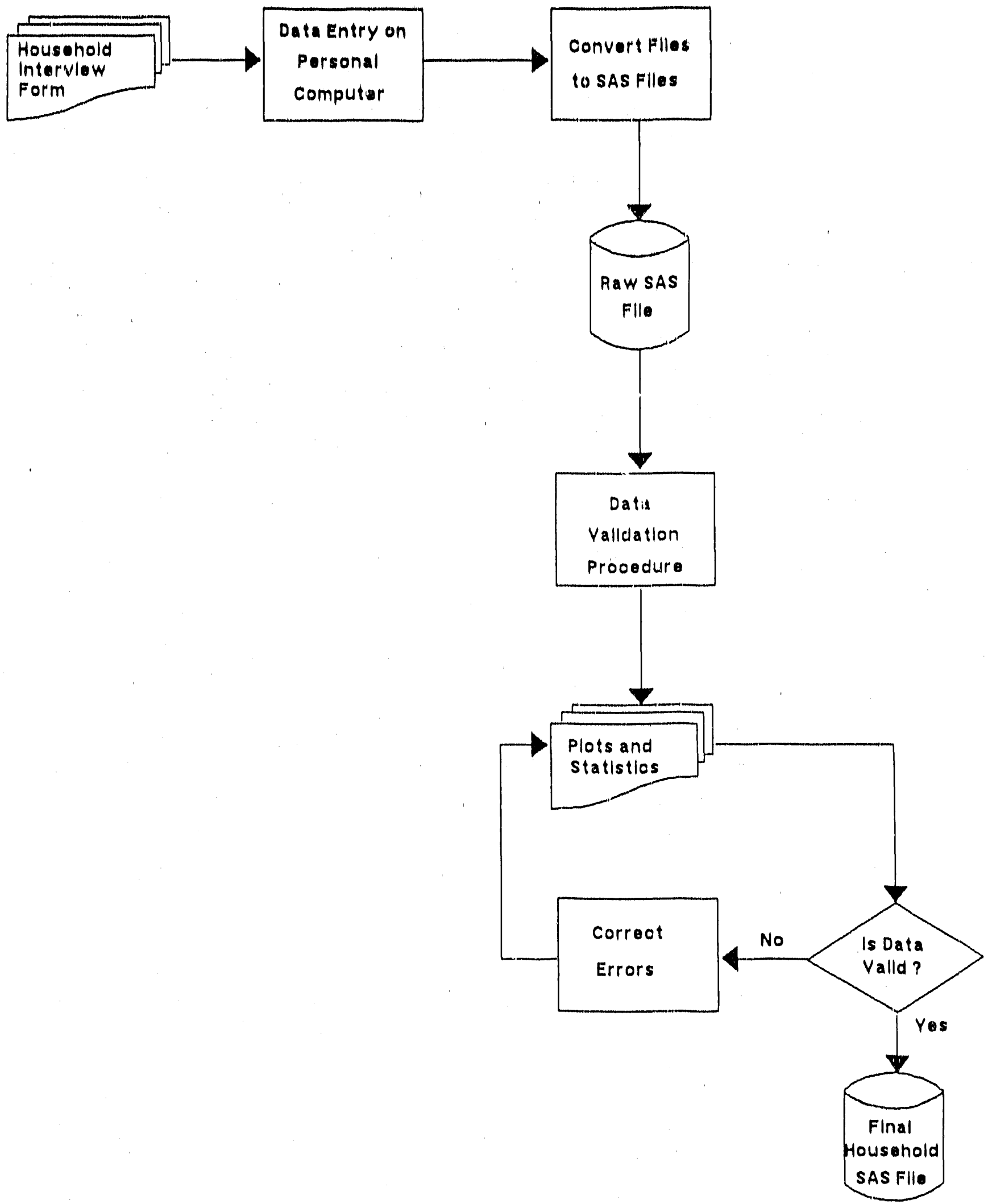

Fig. 6.1. Data management procedure for the survey information. 
North Carolina Flald Tast

Weakly Materad Data

House ID:

Date: (mo $_{1}$ ' Tay -1 year)

House

Electric Meter

$-\ldots-$

Air Conditfoner \#1

Electric Meter

Air Conditioner \#2

Electric Meter
House \# \& Sreet:

Time:

$\overline{(h r}: \frac{}{m i n)} \quad$ a.m.

Water Heater

Electric Meter

$-\cdots$

Furnace Moter

For above ground tanks, enter numbers and mark level

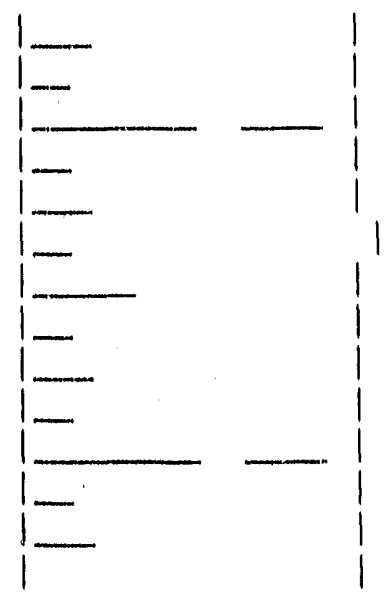

Fig. 6.2. Weekly field data collection form 
will be required to Inoure that untes are always avallable for data collection.

Proossing of consumption, weather, and Indour temperature data w111 be done concurrently so that these files can be meshed together for final storage, As a result, each processed (working) flle will contain all

pertinent information relative to the weekly energy use of an indfuldual house. The flow of data processing for timensequential data is lilustrated In Fig, 6.3 . 


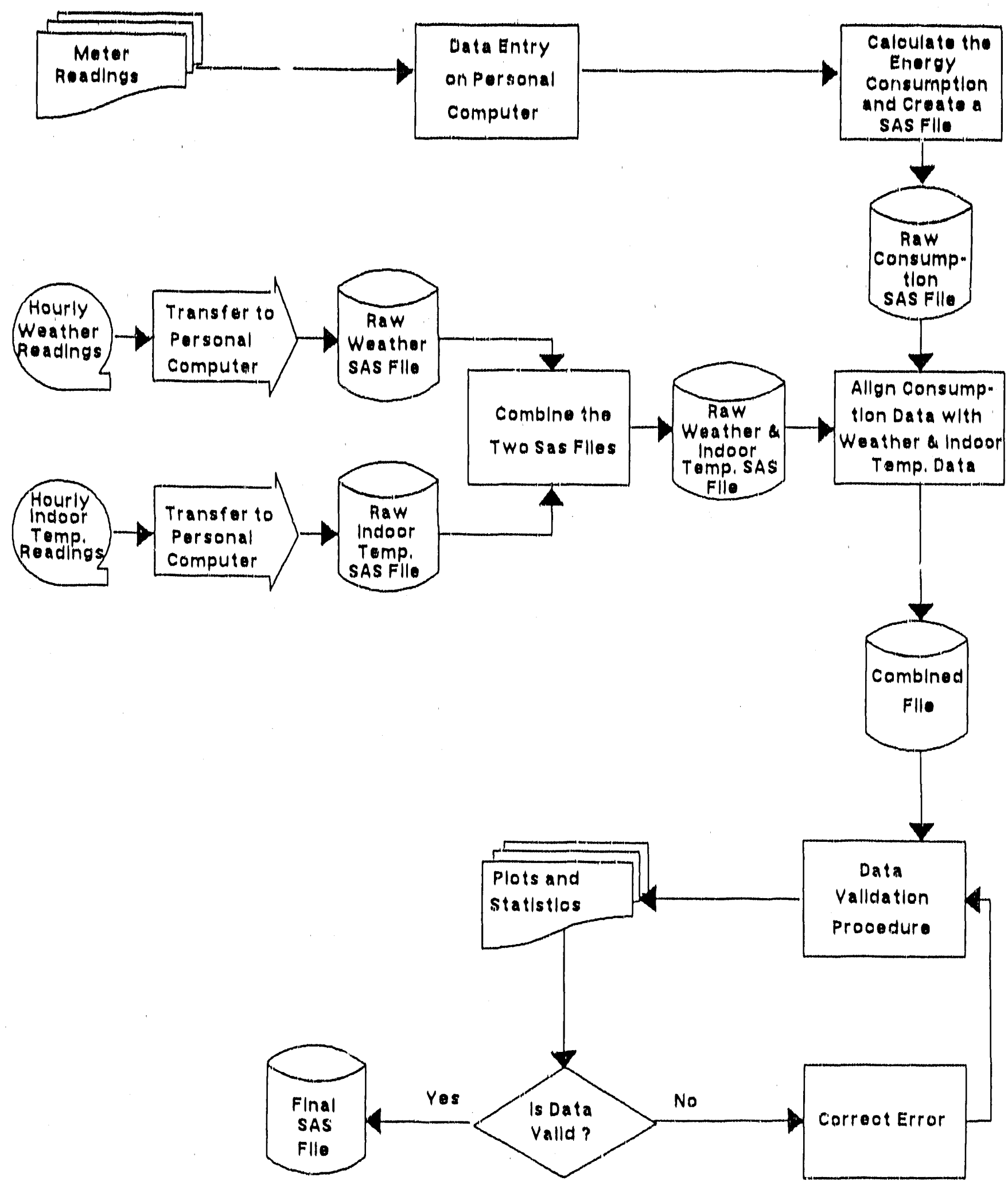

Fig. 6.3. Data management procedure for the time-sequential measurements. 


\title{
7. DATA ANALYSIS
}

\begin{abstract}
Data analysis will be done for both survey information and peiformance data. Analyses should answer questions about house and occupant characterlstios, weatheriation measures, weatherization energy savings, and the performance of the two weatherization approaches, The following sub. seotions detall how these an iyses w111 be done.
\end{abstract}

\subsection{HOUSE AND OCCUPANT CHARACTERISTICS}

Survey information will be used to characterize particlpating houses and their occupants. This will include house type, floor area, wall, floor, and celling/attic constructions, space heating and cooling systems, occupancy levels, occupled perlods, and other characteristics. Summarles w111 be made in tabular and/or graphical form to 1llustrate differences between houses. Comparisons will be made between the pre- and post-weatherization thermal conditions of houses based on insulation levels, Infiltration rates, and heating systern efficiencies. Comparisons will be made between the two treatment groups and the control group. The comparisons will be used to organize houses into subgroups for analyzing performance data and also to Identify differences between houses or groups of houses.

\subsection{WEATHERTZATION MEASURES}

Weatherization measures Installed per the ourrent WAP audit and the Fleld Test Audit will be summarized. This data will be taken from survey information and from the retrofit quality assessment. Summaries will include the most common measures installed by each approach. Comparisons between the two approaches will be investigated using tabular and graphical methods. The weatherization measures summary may help to explaln any differences in energy savings between the two weatherization approaches.

\subsection{ENERGY SAVINGS AND PERFORIANGE}

The energy savings and the performance of the two weatherization approaches will be evaluated for both Individual houses and groups of houses. 
In addition, the performanoe of the approaches w111 bo evaluated based on their cost effectiveness and their ease of implementation.

\subsubsection{Individual House Savings}

Outdoor and Indoor temparatures, humfdty, solar radlation, and occupancy levels are only some of the many factors that influence the energy use of an Individual house. If during testing all of these factors could be held constant over time or caused to vary the same before and after, the annual energy savings due to weatherization would simply be the annual energy use before weatherfation minus the annual energy use after. In reality, many of these factors vary significantly from one year to another (such as outdoor temperature) and therefore can dramatically increase or lower energy use in a spectflc year. If not accounted for, changes in these factors after weatherization can easily mask, inflate, or even show a negative energy savings. This experiment was designed to account for the major influences (or predictors) of house energy use that could be affordably measured (based on past ORNL experience).

Individual house savings will be adjusted (normalized) for differences in outdoor and indoor temperatures, occupant behavior, and possibly salar radiation and outdoor humidity. Occupant related changes will be accounted for by measuring the before and after energy performance of the control houses.

House energy use models w11l be determined that will relate the house energy use to outdoor and Indoor temperatures for both the pre- and postweatherization periods. Linear regression techniques will be used to determine the appropriate coefficlents for each house model. House models w11 be used with average outdoor temperature data based on historical records and "typical" annual indoor temperatures determined from all houses to generate normalized annual energy uses for the before and after weatherization periods of each house. The weatherization savings will be the difference in the before and after energy use minus the average change in the energy consumptions of the control houses (to normalize for occupancy variations). The average change in the energy use of the control houses is simply the 
difference in the energy use predicted by the before period model and the after period model after adjusting for differences in indoor and outdoor temperatures as done in the treatment houses.

Indoor temperature values used for normalization could be based on the indoor temperatures of an individual house for the pre- or post-weatherization periods or some average value across all houses. An average value across all houses will be used so that each house can be normalized to a "typical" base. This should allow comparisons between houses to be made on a more equal basis.

\subsubsection{Group Savings}

A difference between the energy savings for the two treatment groups will be identified using a one-way analysis of variance approach. If the savings from the two groups are found different, this will allow an associated statistical confidence to be determined. Savings differences between groups will be quantified using a multiple comparison technique. The analysis of variance will then be expanded to allow identification of savings differences due to specific influences (such as heating system type, house size, or other characteristic). Groups of houses with similar characteristics will be identified from the house characteristics data.

\subsubsection{Cost Effectiveness of Weatherization}

The cost effectiveness of the two weatherization approaches will be compared. Program comparisons will be based on indicators of program effectiveness, such as energy or dollars saved per dollar expended. Thus, costs for both material and labor associated with each weatherization approach will be collected. Costs will be itemized relative to each measure or task. This will allow procedures common to both weatherization approaches, such as house audits or air-sealing, to be compared on a cost basis.

Actual measure costs will be compared to the assumed measure costs that were used in the Field Test Audit to determine the benefit to cost ratios used for selecting and prioritizing measures. 


\subsubsection{Implementation of the Audit Procedures}

The ease of implementation of the two procedures will be compared based on the experience of the auditors and weatherization installers. Labor requirements for each procedure will be recorded in man-hours. Thus, information will be available for comparing the difficulty of auditing per each procedure and the difficulty of installing measures recommended by each. Some of the data regarding implementation ease will be subjective since it will be collected through questioning of auditors and weatherization installers. 


\section{REFERENCES}

1. Project Retrotech: Home Weatherization Instructor's Guide. U.S. Department of Energy, DOE/CS-0040/1, 1978.

2. M. B. Gettings and J. O. Kolb, Survey Results and Recommendations for WAP Single-and Mult1-family measure selection techniques, Draft Report, Oak Ridge National Laboratory, May 1989.

3. North Carolina Weatherization Assistance Guide, Standards and Techniques, North Carolina Department of Commerce, Assistance Guide 85-F, May 1985.

4. M. P. Ternes, Single-Family Building Retrofit Performance Monitoring Protocol: Data Specification Guideline," ORNL/CON-196, Oak Ridge National. Laboratory, June 1987.

5. I. Miller and J. E. Freund, Probability and Statistics for Engineers, Prentice-Hall, Inc., Englewood Cliffs, New Jersey, 1965.

6. G. V. Fracastoro and M. D. Lyberg, Guiding Principles Concerning Design of Experiments. Instrumentation, and Measuring Techniques, ISBN 91-5403955-X, Swedish Council for Building Research, Stockholm, December 1983.

7. M. P. Ternes and P. S. Hu, The Oklahoma Cooling Retrofit Field Test: Experimental Plan, ORNL/TM-10761, Oak Ridge National Laboratory, January 1989 .

8. "Methods for Determining Air Leakage Rate by Fan Pressurization Test," ASTM Standard E779-81. The American Society for Testing and Materials, Philadelphia.

9. ASHRAE Handbook: 1985 Fundamentals, Chapter 22, American Society of Heating, Refrigerating, and Air-Conditioning Engineers, Inc., Atlanta, 1985. 
APPENDIX A

\section{SURVEY INTERVIEW FORM}

The Survey Interview Form was developed to collect the house and system characteristics data and other interview data as described in Section 5. 


$$
\text { SURVEY INTERVIEW FORM } \quad 8 / 18 / 89
$$

ORNL

Experimental Program: North Carolina Field Test House ID:

Interviewer Name:

Date:

Occupant Name:

House \#\& Street:

City:

State: North Carolina Zip:

County:

Phone Number: ()

Utility Distributors: Electric

Nat'l. Gas

Propane

0 il

Kerosene

HOUSE

Type: __ (MS - multi-story detached; RA - ranch (1 story) detached;

SL - split level detached)

Direction front of house faces: _- (N, NE, E, SE, S, SW, W, NW)

Number of Floors (including basement): __ Approximate Age: __ years

Predominant Roof Type: ___ (V - pitched roof with attic; F - flat roof; P-pitched roof \& ceiling (no attic); X-other)

Is attic or roof cavity ventilated? ( $W$-vented, $N V$-not vented, $Z$-unknown) Ronf Color: __ \& Exterior Wall Color: __ (L-light, M-medium, D-dark) Number of rooms typically closed off: Describe:

Floor Areas :

Floor

Total

Area $(\mathrm{ft} 2)$

Heated
Area $(f+2)$

Cooled ${ }^{* *}$

Basement

First floor

Second floor

Other
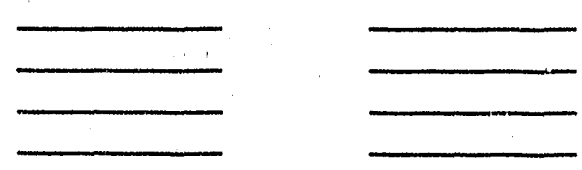

Area (Et2)

Total

* Heated Area: Area of house minus closed off rooms.

** Cooled Area: Area of room with air conditioner ( $A C$ ), or rooms if two ACs. 


\section{OCCUPANCY}

Ownership: _ (OW - own; RE - rent)

Length of time at this address: years

Number of occupants, by age group: Preschool School age Adult, not retired Adult, retired Total

Number of occupants generally home during the day: weekday weekend

\section{SPACE HEATING SYSTEM}

Space Heating Unit 1:

Manufacturer: Model: Approx. Age: yrs

Fuel: (G-nat' 1 gas, P-propane, K-kerosene, $01-\# 1$ o11, 02-\#2 oil)

Type: SH-space heater; F-central furnace; FF-floor furnace; CH-ceiling heat; $\overline{E B-e l e c t r i c ~ b a s e b o a r d ; ~ B-b o l l e r ; ~ W H P-w i n d o w / w a l l ~ h e a t ~ p u m p ; ~ X-o t h e r) ~}$

Distribution fluid: (A-air, w-water, S-steam, Z-unknown, X-other)

Distribution method: (F-forced; G-gravity; Z-unknown)

Input rating: \& untes: (B-Btuh, GM-gal/min, X-other)

Output capacity: Btu,h Efficiency rating: (if rated)

Location: _ (NC - non-conditioned space or outside air intake provided; IC - intentionally conditioned space; UC - unintentionally conditioned space)

Answer Is this a converted coal unit? or converted oil unit?

$\mathrm{Y}$ or $\mathrm{N}$ : Is an intermittent ignition device used? If oil flred, is a flame retention head burner used? If a pilot is used, is it turned off during the summer?

Is a vent damper used: (T-thermal; E-electric; N-no; NA-not applicable) 
Space Heating Unit 2:

Manufacturer:

Mode1:

Approx. Age: yrs

Fue 1: (G-nat'l gas, P-propane, K-kerosene, 01-\#1 o11, 02-\#2 o11)

Type: SH-space heater; F-central furnace; FF-floor furnace; CH-celling heat; $\overline{E B-e l e c t r i c ~ b a s e b o a r d ; ~ B-b o l l e r ; ~ W H P-w i n d o w / w a l l ~ h e a t ~ p u m p ; ~ X-o t h e r) ~}$

Distribution fluid: (A-air, W-water, S-steam, Z-unknown, X-other)

Distribution method: (F-forced; G-gravity; Z-unknown)

Input rating:

\& units: (B-Btuh, GM-gal/min, X-other)

Output capacity: Btu/h Efficiency rating: (1f rated)

Location: (NC - non-conditioned space or outside air intake provided; IC - intentionally conditioned space; UC - unintentionally conditioned space)

Answer Is this a converted coal unit? _ or converted ofl unit? $\mathrm{Y}$ or $\mathrm{N}$ : Is an intermittent ignition device used? If oil fired, is a flame retertion head burner used? If a pilot is used, is it turned off during the summer? -

Is a vent damper used: (T-thermal; E-electric; N-no; NA-not applicable)

Space Heating Unit 3:

Manufacturer:

Mode1:

Approx. Age: yrs

Fuel: (G-nat' 1 gas, P-propane, K-kerosene, $01-\# 1$ o11, $02-\# 2$ oil)

Type: SH-space heater; F-central furnace; FF-floor furnace; CH-ceiling heat: EB-electric baseboard; B-boiler; WHP-window/wall heat pump; X-other)

Distribution fluid: (A-air, W-water, S-steam, Z-unknown, X-other)

Distribution method: (F-forced; G-gravity; Z-unknown)

Input rating: \& units: (B-Btuh, GM-gal/min, X-other)

Output capacity: Btu/h Efficlency rating: (1f rated)

Location: (NC - non-conditioned space or outside air intake provided; IC - intentionally conditioned space; UC - unintentionally conditioned space)

Answer Is this a converted coal unit? or converted oil unit? $\mathrm{Y}$ or $\mathrm{N}$ : Is an intermittent ignition device used? If oil fired, is a flame retention head burner used? If a pilot is used, is it turned off during the summer?

Is a vent damper used: (T-thermal; E-electric; N-no; NA-not applicable) 
Auxillary heating use:

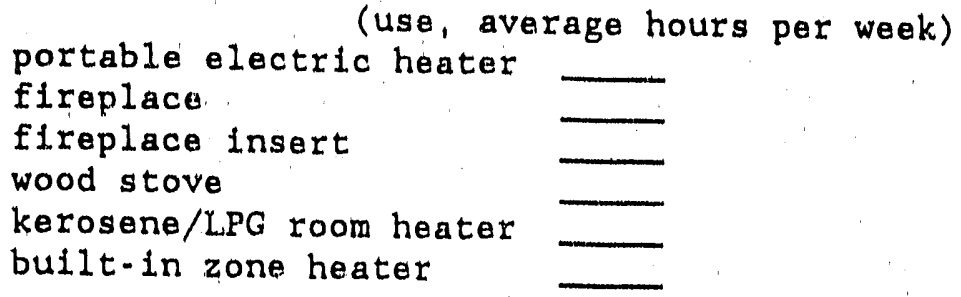

\section{Distribution System}

Total length of ducts or piping: feet

Length of ducts or piping in unconditioned space: feet

Insulation thickness of ducts in unoonditioned space: inches

Thermostat

Manufacturer:

Mode 1:

Type: (R-regular; C-clock, N-none; X-other)

Number of thermostats:

\section{COOLING SYSTEM}

Alr Conditioner \#1:

Manufacturer:

Mode 1:

Fue 1: $\mathrm{E}$

Output capacity: $\mathrm{Btu} / \mathrm{h}$

Approximate age: years

Voltage: 110 or 22.0

Location: (which room)

Air Conditioner \#2:

Manufacturer:

Model:

Fue 1: $E$

Output capacity:

$\mathrm{Btu} / \mathrm{h}$

Approximate age: years

Voltage:

110 or 220

Location:

(which room) 
HOT WATER SYSTEM

Manufacturer:

Model:

Fuel Type:

(E-electric; G-nat' 1 gas; P-propane, 0-o11, M-mixed; $X$ - other)

Storage: __ (T. storage tank; L - tankless; $Z$ - unknown)

Heater Type: __ ( $R$ - standard residential; $B$ - boller; X - other; $Z$ - unknown)

Tank Size: gallons

Water Temperature (measure): ${ }^{\circ} \mathrm{F}$

Input: watts

Recovery:

External blariket insulation thickness: inches

Location: (NC - non-conditioned space or outside alr intake provided; IC - Intentionally conditioned space; UC - unintentionally conditioned space)

Appliance

Cooking range Conventional oven Microwave oven Clothes washer Clothes dryer Refrigerator Separate freezer Dishwasher Whole house fan Attic fan Other (identify)

\section{APPLIANCE'S}

\section{Fue1 Location}

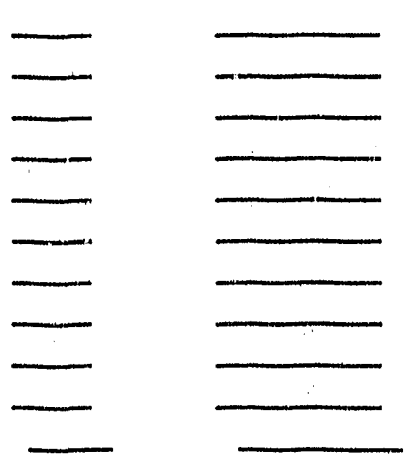

Fue 1: E - electricity;

G - nat'1. gas ;

P - propane;

$X$ - other

Location: NC - non-cond1tioned space or outside alr provided; IC. intentionally conditioned space; UC unintentionally conditioned space 
ATIIC or RoOH (1f ne att to)

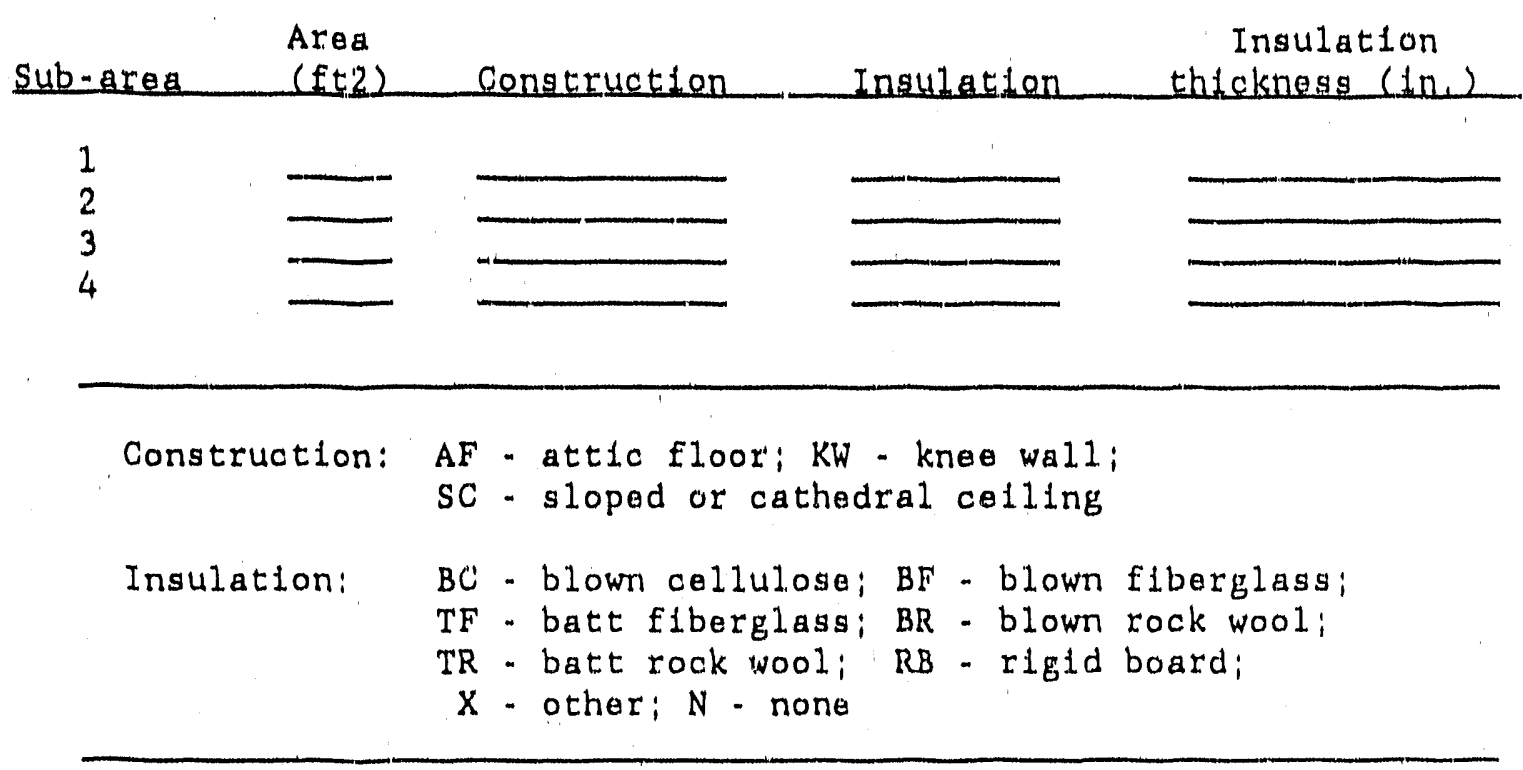

EXTERIOR WALLS

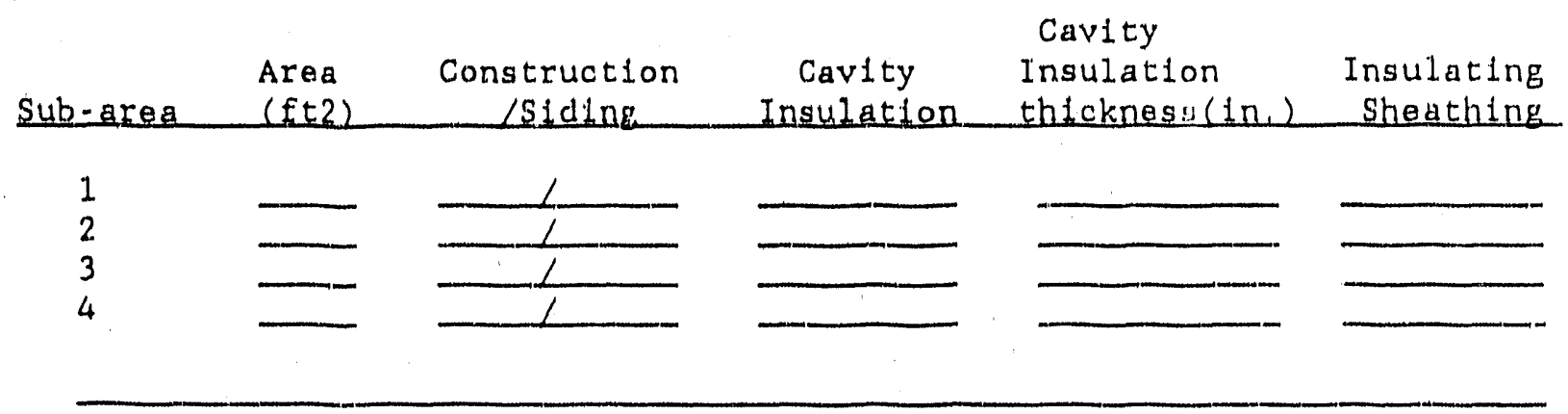

Construction: FR - frame; CB - concrete block; X - other

Siding: W- wood; BR - brick; SN - stone; SC - stucca;

SI - aluminum, steel, or vinyl; SH - shingle;

SL - slate; N none; X - other

Insulation: $B C$ - blown cellulose; $B F$ - blown fiberglass;

TF " batt fiberglass; RB - rigld board;

$\mathrm{BR}$ - blown rock wool; TR - batt rock wool;

$\mathrm{X}$ - other; $\mathrm{N}$ - none

Insulating sheathing: F-foam:rigid; FBD-flberboardimineral, wood, or vegetable; FG-fiberglass:rigld; X-other; $N$ - none 
SUB FLOOR

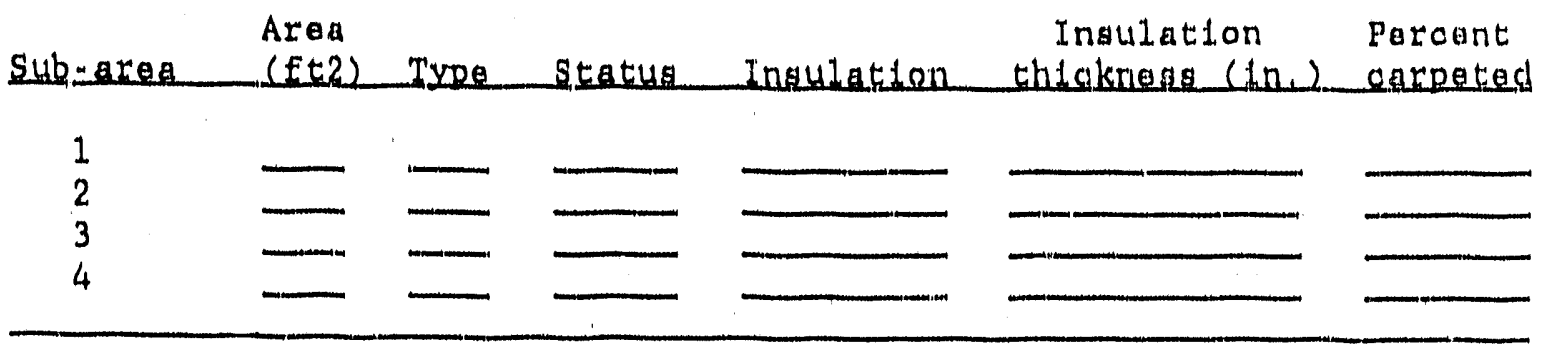

Type: B - above basement; $S$ - slab; $C$ - above crawl space; $X$ " other

Stacus: NC - non-condftioned space below floor:

IC - Intentionally conditioned space below floor:

$U C$ - unintentionally conditioned space below floor

Insulation: $T F$ - batt fiberglass; TR - batt rock wool;

$R B$ - rigld board; $X$ - other; $N$ - none

\author{
FOUNDATION \\ Predominant type: _- (B - basement; S - slab; C - oxawl spaca; \\ $X$ - other) \\ Foundation Walls: (none if glab-on-grade)

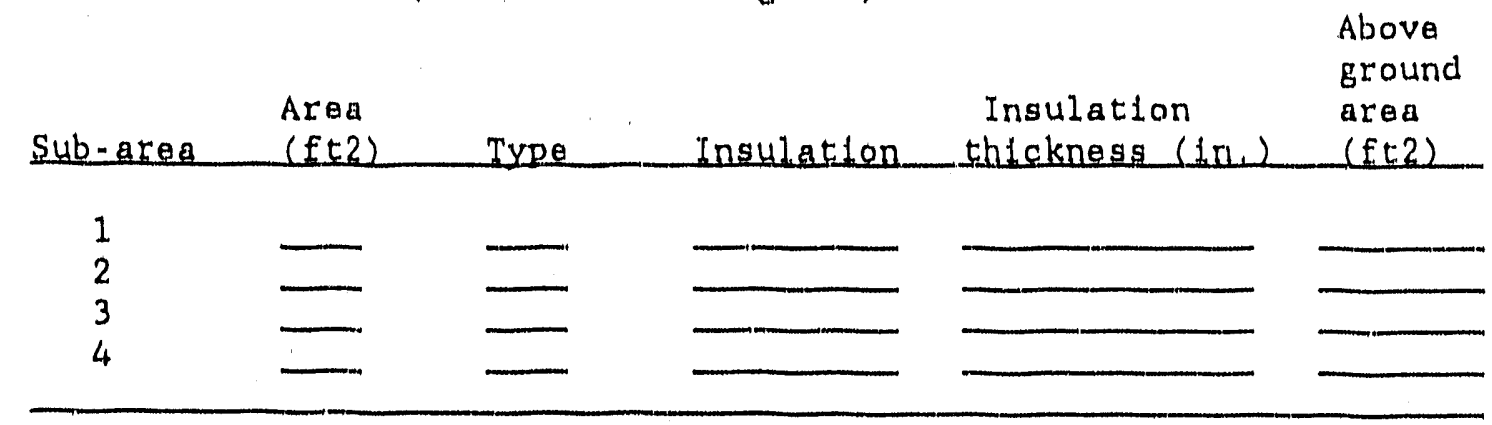 \\ Type: $C B$ - concrete block; $M A$ - masonry (concrete); P - pillars; \\ $S$ - stone; X - other \\ Insulation: TF - batt flberglass; RBI - Interfor rigid board; \\ RBE - exterior rigld board; FI - Interior foam; \\ $F E$ - exterior foam; $S$ - skirting; $X$ - other; $N$ - none \\ Are the sill boxes or band folsts insulated: _- ( $Y$ - yes; $N$ - no; \\ NV - not visible; \\ NA " not applicable)
}




\section{WINDOWS AND DOORS}

Predominant window type: _- (CA - oasement; DH - dollble hung:

FX - flxed; X - other)

Are external shades, shutters, or films Installed?

$(Y \cdot y \in s ; N \cdot$ no $)$

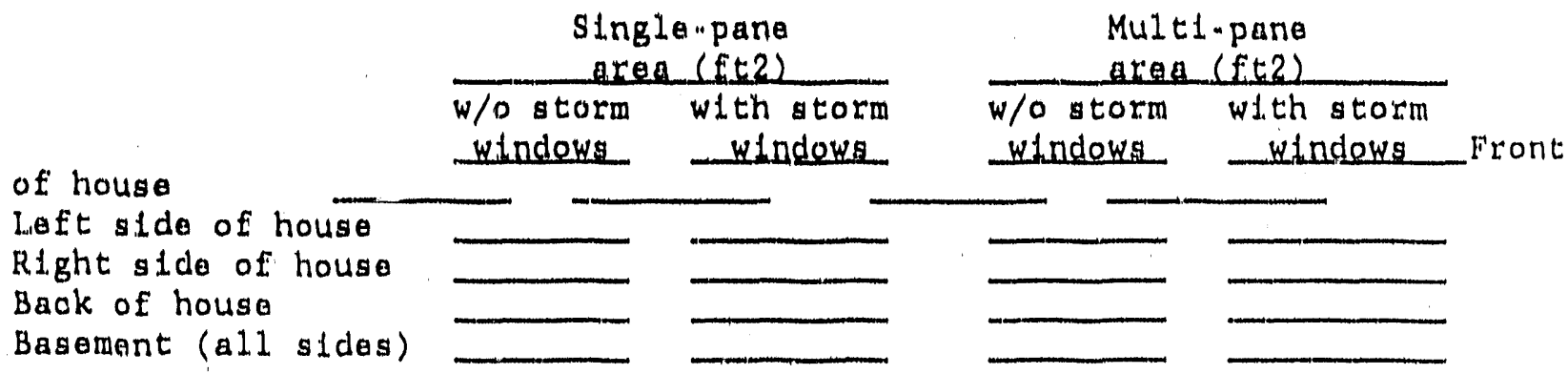

Are storm doors installod? _- Y or $\mathrm{N}$ 


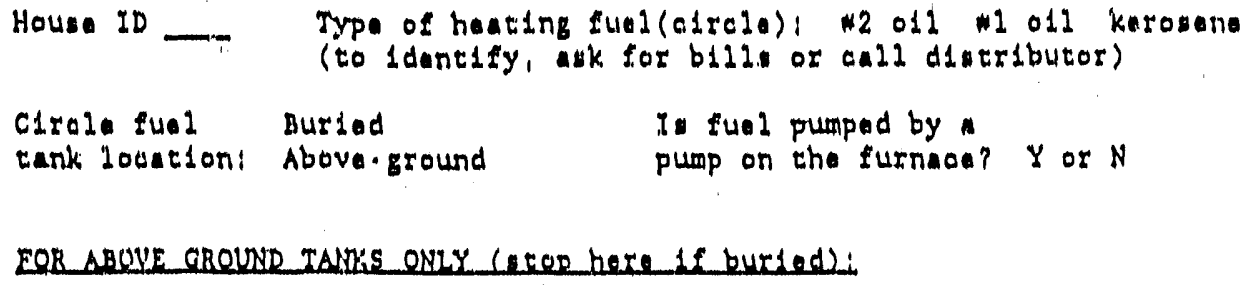
$\ln$.

Ob. round tanks (no okotah):

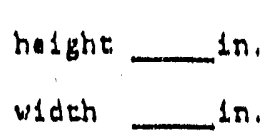

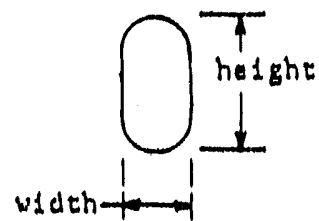

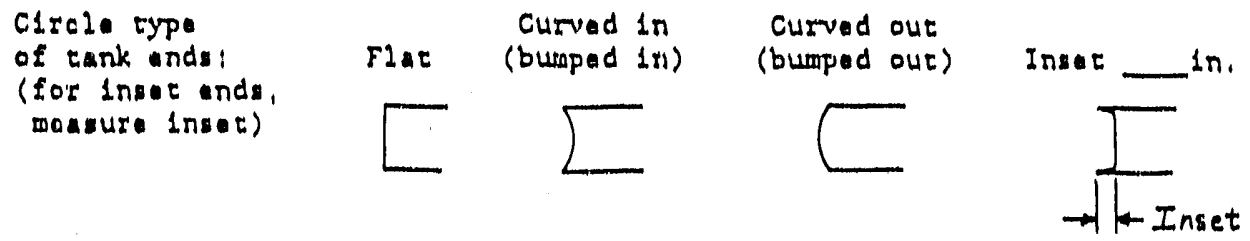

Chock rark levalnosn, use 24 " lovel (24" only). Set luvel on top of tank (avold ridges in lank wall) and add spacing materlal undar ene ond to bring to lovel. Ingura lovol is in lino wh the tank. Masura distanca from top of tha rank to the botrom of the ralsod and of the lovel (sou sketch).

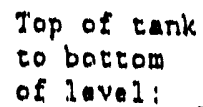
$\ln$.

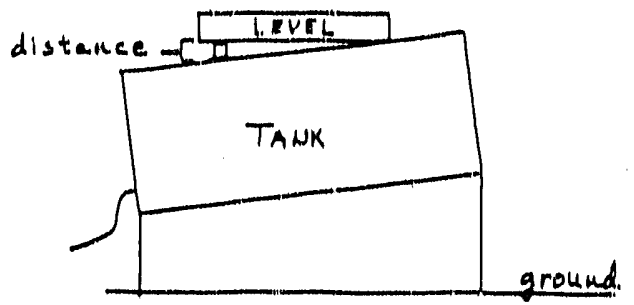

Slope of rank: (c1relo ona) (sou sketches) or

2.) away from furnuen Iino
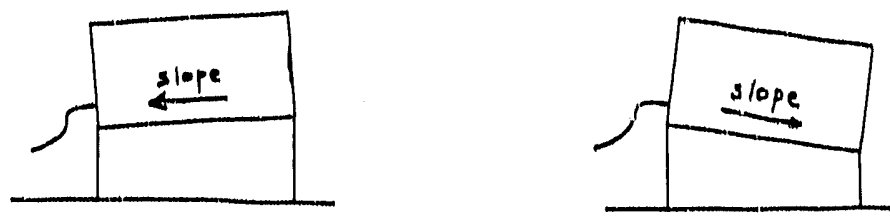


\section{SKOTCH OE HOUSE LAYOUT}

House ID:

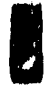

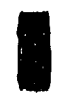

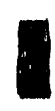

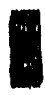

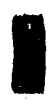

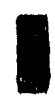

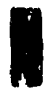

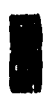

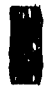

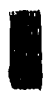

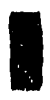

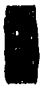

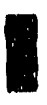

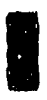

,

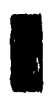

